\title{
The Late Weichselian to Holocene succession of the Niedersee [Rügen, Baltic Sea] - new results based on multi-proxy studies
}

\author{
Annette Kossler, Jaqueline Strahl
}

Abstract:

The locality of the Niedersee, situated directly on the south-eastern cliff line of the Jasmund Peninsula (Isle of Rügen, Baltic Sea), is a classical Late Glacial site. The small kettle hole depression of the Niedersee reveals an excellent archive for palaeoenvironmental and palaeoclimatic reconstructions. Here, a new research was performed which provides more detailed and precise knowledge of the local development during the Last Glacial-Interglacial Transition, because especially the Weichselian Late Glacial is completely preserved here. Dating is based on pollenstratigraphy, AMS ${ }^{14} \mathrm{C}$-measurements, and the proof of the Laacher See Tephra (LST). The sedimentary record of the Niedersee, ranging from the Weichselian Pleniglacial to the Preboreal $(\sim 15,000-\sim 10,000$ cal. years BP), can mainly be traced back to small, shallow lacustrine environments, which were repeatedly affected by fluctuating water levels. This led subsequently to a hiatus within the sedimentary succession in the course of the Preboreal. Sedimentation ultimately continued during the Atlantic and ceased with the development of an alkaline fen. The combined data of the rich pollen-, micro- and macrofossil record (e.g. ostracods, molluscs, plant remains, etc.) of the Niedersee prove to be an excellent tool to reveal the changing climate conditions and their influence on the regional palaeoenvironments.

[Die weichselpleniglaziale bis holozäne Schichtenfolge des Niedersees [Rügen, Ostsee] - neue Ergebnisse durch Multiproxy-Untersuchungen]

Kurzfassung:

\begin{abstract}
Eine klassische weichselspätglaziale Lokalität ist die kleine Toteishohlform des Niedersees, welche direkt an der südöstlichen Küste der Halbinsel Jasmund (Rügen, Ostsee) aufgeschlossen ist. Neue Studien wurden durchgeführt, bei denen sich die sedimentäre Abfolge des Niedersees als ein hervorragendes Archiv für paläoökologische/-klimatische Rekonstruktionen erwies, wodurch detaillierte Aussagen zur regionalen Vegetationsgeschichte sowie zum regionalen Klima und Milieu während des Weichselspätglazials und auch teilweise für das Holozäns möglich sind. Mit Hilfe der Pollenstratigraphie, AMS ${ }^{14} \mathrm{C}-\mathrm{Datierungen}$ und dem Nachweis der Laacher See Tephra konnte die sedimentäre Abfolge in die bestehende Quartärstratigraphie eingehängt werden; als Besonderheit ist hier das quasi gesamte Weichselspätglazial vollständig aufgeschlossen. Die Sedimentation beginnt schon im ausgehenden Weichselhochglazial und dauert zunächst bis zum Präboreal an ( 15.000- 10.000 Jahre v. H.) und ist vor allem durch Ablagerungen eines kleinen, flachen Sees charakterisiert. Änderungen im Wasserhaushalt führten letztendlich während des Präboreals zu einem Hiatus. Eine letztmalige Vernässung des Standorts führte im Atlantikum zur Entwicklung eines kalkigen Niedermoors. Die sich ergänzenden Analysen der verschiedenen und vielfältigen Organismenreste des Niedersees (z. B. Pollen, Ostracoden, Mollusken, Makroreste von Pflanzen etc.), erlaubten in sehr detaillierter Weise Änderungen im Klima und deren Auswirkungen auf das Habitat zu erfassen.
\end{abstract}

Keywords: $\quad$ Northern Germany, Rügen, Weichselian Late Glacial, pollen analyses, climate, multi-proxy studies

Addresses of authors: A. Kossler, Free University Berlin, Institute of Geological Sciences, Section Palaeontology, Malteserstr. 74-100, Haus D, 12249 Berlin, Germany. J. Strahl, Geological Survey of Brandenburg (LBGR), Branch Geology, Inselstraße 26, 03046 Cottbus, Germany.

\section{Introduction}

The coast line of the Jasmund Peninsula (Isle of Rügen, Baltic Sea) is a frequently visited location for geological excursions offered by the public relations of the Biosphere Reserve SE-Rügen. Especially the impressive scenery of the Cretaceous chalk cliff is always of particular interest. But the south-eastern cliff line of the Jasmund Peninsula between Sassnitz and Mukran reveals another specific geological feature, because several different deposits of the youngest Weichselian glaciation and the Holocene are well-exposed here. An often inspected excursion point there is the locality of the Niedersee, a classical Late Glacial site, which was already studied by BOEHM-HARTMANN (1937), KRASSKe (1937), and StEuSLOFF (1937).

The small depression of the Niedersee, which has a diameter of approximately $40 \mathrm{~m}$, can be traced back to a kettle hole just as the adjacent depressions of the Credner See, the Mukraner See, and the Hölle (see Fig. 1). Today, these kettle holes have been cut off by the wave activity of the Baltic Sea, which caused destructive coastal erosion. This coastal erosion offers an insight into the history of their development. The discovery of these kettle holes situated directly at the present cliff line took place in the 1930s. At first, CREDNER detected a depression of a former lake in the upper part of the $15 \mathrm{~m}$ high cliff wall in 1932, which was later called Credner See according to its discoverer. Then, also in 1932, THIENEMANN found the depression of the former Mukran See at the cliff wall slightly to the north and in 1933, together with BoEHM-Hartmann, the depression of the Niedersee. The latter is located between the former depressions listed above (Fig. 1). The German name Niedersee was derived from the low height of the cliff at this point, which is only $4 \mathrm{~m}$ high.

In general, kettle holes are typical and frequent morphological features of the glacial topography of Jasmund. Embedded in the undulating ground moraine landscape, these small depressions exist here in great quantities. Their formation resulted from the glacial activity during the Pomeranian and Mecklenburg phases of the Weich- 


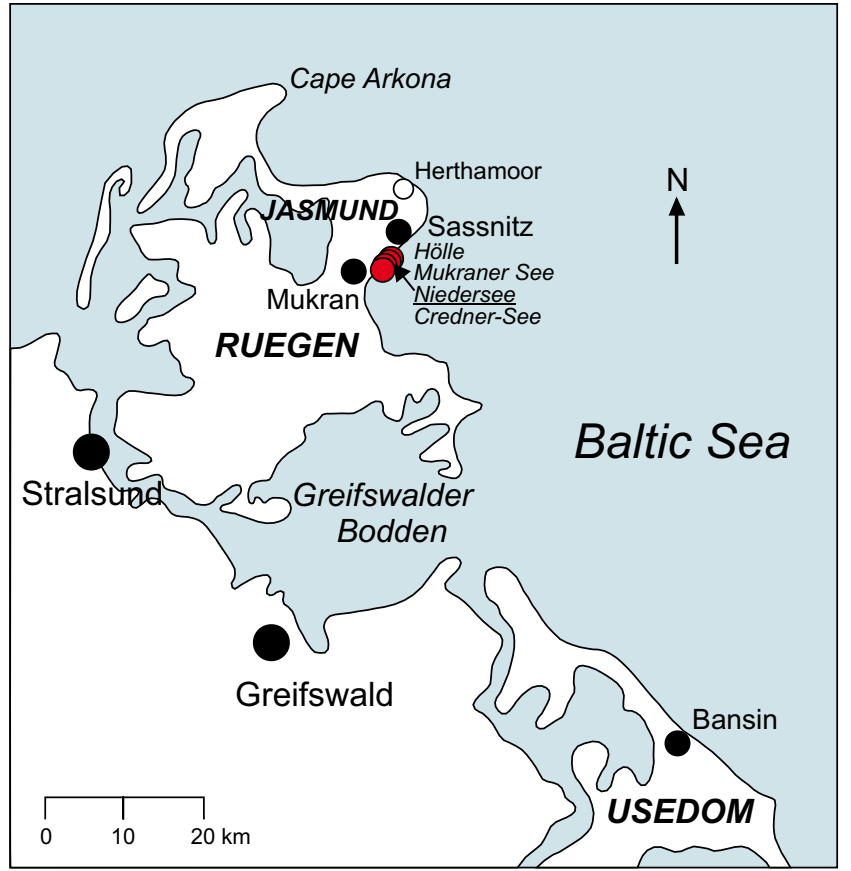

Fig. 1: Location of the Niedersee and of the adjacent Mukran See, Hölle (today both abraded), and Credner See at the cliff line between Sassnitz and Mukran, Peninsula fasmund (Rügen).

Abb. 1: Lage des Niedersees und der Aufschlüsse Hölle, Mukraner See (beide heute abradiert) und Credner See an der Küste zwischen Sassnitz und Mukran, Halbinsel Jasmund.

selian Pleniglacial (qw 2/3 in KRIENKE 1996, 2003). Kettle holes were generated after the dead ice melted and the resulting depressions were often filled with water forming small lakes without outlet, of which several still exist today. Subsequently, these small depressions like the abovementioned are often filled with limnic/telmatic sediments of the Weichselian Late Glacial and the Holocene (BoEMHARTMANN 1937; LANGe, JeschKe \& KNAPP 1986; Strahl \& KEDING 1996).

First studies on the sedimentary record of these former lakes were performed by BoEHM-HaRtmanN (1937: pollen analyses), Steusloff (1937: molluscs) and Krasske (1937: diatoms). But especially concerning the Niedersee, no modern studies about the history of this lake have been realised and published since then. Originally, BoEHm-Hartmann (1937) stated that the sediments of the Niedersee, the Credner See, and the Mukran See have only a Holocene age (Preboreal to Atlantic). Although the sedimentary successions of these three former lakes differ in thickness and sedimentary formation, they can be partially correlated due to the occurrence of contemporaneous peat layers within their sedimentary record. Based on modern pollen analyses, a more recent revision of the Credner See (LANGE, JESCHKE \& KNAPP 1986) has proven a significantly older age reaching from the Weichselian Late Glacial (youngest Allerød Interstadial) until the Holocene (youngest Atlantic). The proof of the Laacher See Tephra (LST) within the sedimentary record of the Credner See (KLIEwE 1996; De KLERK et al. 2008) additionally confirmed this revised stratigraphic range. The LST was also found within the Niedersee record by KLIEWE (1996), which also indicates that the sediments must be older than Holocene. Furthermore, in com- parison with the sedimentary records of the Credner and Mukran See, the distinctly thicker sedimentary succession of the Niedersee strongly suggests an earlier onset of sedimentation. To clarify the stratigraphic position of the Niedersee, new sections were excavated and documented by ANDERS \& STRAHL in 1986 (unpublished, see Fig. 2), but further studies were no longer conducted (STRAHL, pers. comm.). Nevertheless, it became evident that the Niedersee reveals an excellent archive for palaeoenvironmental and palaeoclimatic reconstructions that, moreover, will provide sediments of pre-Allerød age. Now, based on multi-proxy studies (pollen, plant macro remains, ostracods, molluscs, etc.) a new research on two new sections of the Niedersee (Fig. 2) is presented here which allows for a more detailed and precise reconstruction of the development of regional vegetation and environmental history during the Late Glacial and early Holocene.

\section{Study site, materials and methods}

The depression of the Niedersee (Fig. 1), once a small lake, is located directly at the present cliff line (topographic map 25: 1547, Binz, R: 4604 078, H: 6041 744). Whereas up to the 1990s the out crop of the Niedersee was easily accessible and well-preserved, the centre of the depression is now highly buried and rehydrated due to a drainage ditch of the neighbouring golf course. Therefore, site inspection and sampling was no longer possible in this part of the depression. Another problem consist of the increasing coastal erosions that have taken place in the last years, which have yet abraded the deposits of the Mukran See, the Hölle and, unfortunately, parts of the Niedersee as well. For these reasons, in May 2006 the two new sections could only be excavated at the still accessible southern and northern margins of the Niedersee depression. To correlate the new sections with the older ones from 1933 (BoEHM-HARTMANN 1937) and 1986 (ANDERS \& STRAHL, unpublished), the top of the youngest peat horizon (Holocene, Atlantic) was used (see Fig. 2).

To obtain the samples for pollen analyses, u-shaped metallic profiles $(100 \mathrm{~cm}$ length $/ 10 \mathrm{~cm}$ breadth $/ 5 \mathrm{~cm}$ depth) were pressed into the sediments. This was done vertically to the bedding to maintain sediment cores. Consequently, three successive sediment cores with sufficient overlaps were taken from the southern margin of the Niedersee depression and later combined to a $2.09 \mathrm{~m}$ long sediment record. The obtained sediment record was used for detailed sediment descriptions and subsequently sub-sampled for pollen analyses. Sampling was regularly carried out every five centimetre; sampling density was sometimes adapted to the sedimentary features. A total of 45 samples (each of approx. $1 \mathrm{~cm}^{3}$ sediment) were taken from the sediment cores (see Fig. 3). In contrast, the sedimentary succession of the $2.35 \mathrm{~m}$ thick northern section (Fig. 2) was directly sampled in the field every $25 \mathrm{~cm}$.

The preparation of the pollen samples was performed in the pollen laboratory of the State Laboratory Berlin-Brandenburg (LLBB) in Kleinmachnow. Samples were treated with $\mathrm{HCl}, \mathrm{KOH}$, acetolysis und ultrasonic sieving $(6 \mu \mathrm{m})$ to receive liquid preparations (suspensions). For recognizing siliceous materials like diatoms or for identifying the 


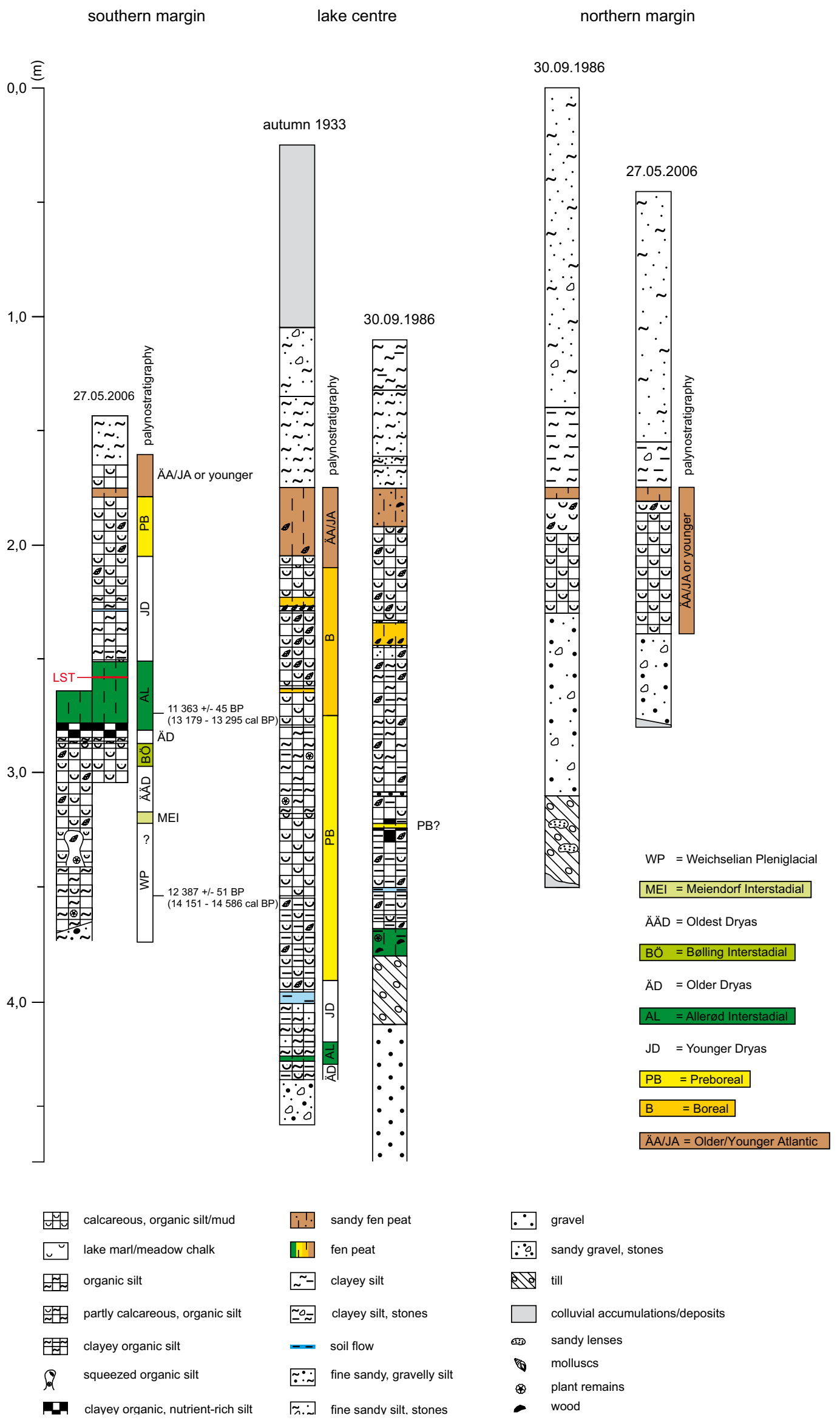

Fig. 2: Sections from the southern margin, from the centre and from the northern margin of the Niedersee depression showing stratigraphic ranges and sedimentology. The section of 1933 (BOEHM-HARTMANN 1937) is here presented in a revised and modified version. The top of the uppermost fen peat horizon ( $\ddot{A} A / \mathcal{F} A$, Atlantic) is used to correlate the different sections.

Abb. 2: Zusammenstellung der aus dem Niedersee aufgenommenen und z. T. paläontologisch bearbeiteten Profile vom Herbst 1933 (BOEHM-HARTMANN 1937, Pollenstratigraphie aktualisiert), vom 30.09.1986 (ANDERS \& STRAHL 1986, unpubl.) sowie vom 27.05.2006. Die Oberkante des jüngsten Niedermoortorfs ( $\ddot{A} A / \mathcal{F} A$, Atlantikum) dient hier als Bezugshorizont. 
Laacher See Tephra (LST) no routine treatment with HF (40\%) was carried out.

Generally, a sum of up to 400 pollen grains was counted. The results are presented in percentage terms, in which the ratio arboreal pollen (AP) to non-arboreal pollen (NAP) corresponds to the basic sum of $100 \%(\Sigma(\mathrm{AP}+\mathrm{NAP})=$ $100 \%)$. The pollen, spores and cysts of local components like aquatic plants, marsh plants, ferns, moss, algae as well as reworked pre-Quaternary sporomorphs are excluded from this basic sum, with the exception of the Cyperaceae. Nonetheless, like the individual AP and NAP records these proofs are applied to the basis sum as well. The results of pollen analyses are shown in a conventional pollen diagram (Fig. 3). Curves are exaggerated tenfold for making values below $1 \%$ visible. Rare findings of taxa are not illustrated within the pollen diagram, but will be partly mentioned in chapter 3 .

For extracting further macro- and microfossils (e.g. ostracods, molluscs, plant macro remains etc.) from the sediments, additional sediment samples were taken parallel to the pollen sampling. In contrast to the dense pollen sampling, only 21 samples (M1 up to M21, see Fig. 3) of approx. $1 \mathrm{~kg}$ weight have been removed from the southern margin of the Niedersee depression, because greater amounts of material are generally necessary to receive enough macrofossil remains. In general, sampling followed the changes in sedimentology. Correlation of samples is illustrated in Fig. 3. Preparation of these samples was carried out at the palaeontological laboratory of the Institute of Geological Sciences of the Free University Berlin. Samples were dried and then treated with 3,5\% hydrogen peroxide for 24 hours, suspended in water and washed through $1 \mathrm{~mm}$, $500 \mu \mathrm{m}, 250 \mu \mathrm{m}$ and $125 \mu \mathrm{m}$ sieves. Fossil remains within the residues were picked out, sorted and identified using a Leica S6E and a Zeiss Axiostar plus microscope. Head capsules of chironomids, which are preserved in sediments of the Younger Dryas and the Preboreal (Fig. 7), were mounted on a microscope slide in Euparal.

For documentation selected specimen were mounted on stubs, sputtered with gold and examined with the aid of a Zeiss Supra 40 VP scanning electron microscope (SEM).

Two radiocarbon measurements were obtained from terrestrial plant remains. AMS ${ }^{14} \mathrm{C}$-dating were performed at the Leibniz Radiocarbon Laboratory in Kiel (KIA 33255, sample M1; KIA 33256, sample M9).

Except if otherwise noted, the presented results in chapter 3 apply to the section from the southern margin of the Niedersee depression.

\section{Results, discussion and interpretation}

The data from the sedimentary record of the southern margin of the Niedersee document an early initiation of the limnic sedimentation. Over relocated moraine deposits, sedimentation starts with sandy and gravely silts (Fig. 2). The first traceable pollen record is proven from these sediments and its onset is here defined as base line of the section (Fig. 2, 3). Based on the pollen spectra composition, nine pollen zones could be recognized, which, in combination with other proxy data and AMS ${ }^{14} \mathrm{C}$-dating, allow for well-founded age determination. The chronology used here corresponds to the stratigraphical classification that is employed for Mecklenburg-West Pomerania (MüLler 2004), Berlin/Brandenburg (STRAHL 2005) and Northern Germany (LiTT et al. 2007) as well. But it is contrary to the stratigraphical subdivision of the Mecklenburg-West Pomeranian Late Glacial deposits stated in TERBERgER et al. (2004). For detailed discussions and an evaluation of this deviant classification, and further debatable information, e.g. the correlation with the Greenland NGRIP ice-core (JoHNSEN et al. 1997; BJÖRCK et al. 1998) in GÖRSDORF \& KAISER (2001), see the comments to the pre-Allerød development of sedimentary processes and vegetation in STRAHL (2005).

\subsection{Development of the Niedersee during the Last Termination and the Holocene}

\subsubsection{Pleistocene}

\subsubsection{Section interval 0-0.33 m: Termination of Weichselian Pleniglacial}

The lowermost section interval is characterized by layers of greyish fine sandy, gravely silts, which are overlain by bluish-grey organic silts. Sediments are partly calcareous. Mollusc shells, plant remains and little enrichments of humus are partly visible.

The pollen record of the lowest part of the Niedersee section ( $0-0.3 \mathrm{~m}$ of section) is attributed to the first pollen zone (= WP in Fig. 3, Weichselian Pleniglacial). It shows high percentages of grasses and herbaceous taxa (Fig. 3), mainly consisting of sedges (Cyperaceae), true grasses (Poaceae), mugwort (Artemisia) and plantain (Plantago). Subordinated occur yarrow (Achillea), bedstraw (Galium), meadow-rue (Thalictrum), sunrose (Helianthemum), willowherb (Epilobium), breakstone (Saxifraga), crowberry (Empetrum), sorrel (Rumex), thrift (Armeria), heather (Ericaceae p.p., Calluna), and pollen of Rosaceae, Umbellifereae, Gentianaceae, Caryophyllaceae, Asteraceae (Tubuliflorae, Liguliflorae) and Chenopodiaceae. Arboreal pollen are mainly dominated by pine (Pinus), but these pollen stem most likely from reworked material of older Quaternary or pre-Quaternary deposits. This applies especially to the pollen of warm and temperate woody taxa such as hazel (Corylus), elm (Ulmus), oak (Quercus), alder (Alnus) and hornbeam (Carpinus) as well. High percentages of reworked pre-Quaternary sporomorphs in this part of the diagram support this interpretation. In contrast, the pollen of birch, especially of dwarf birch (Betula nana), of dwarf willow (Salix spp.), and, in lower quantities, of seabuckthorn (Hippophaë rhamnoides) and juniper (Funiperus) are most likely of autochthonous origin. Pteridophytes are proven by horsetail (Equisetum), moonwort (Botrychium), and spike moss (Selaginella selaginoides), whereas the high percentages of monolete spores of ferns (up to $36 \%$ ) can also be traced back to reworked material, because their maximum correlates with the peak of pre-Quaternary sporomorphs. Further marsh and aquatic plants, which are likely to belong to the local vegetation, are rarely represented by pollen of bog star (Parnassia palustris), pondweed (Potamogeton), spiked water-milfoil (Myriophyllum spicatum), greater reed mace (Typha latifolia), reed mace/bur reed 


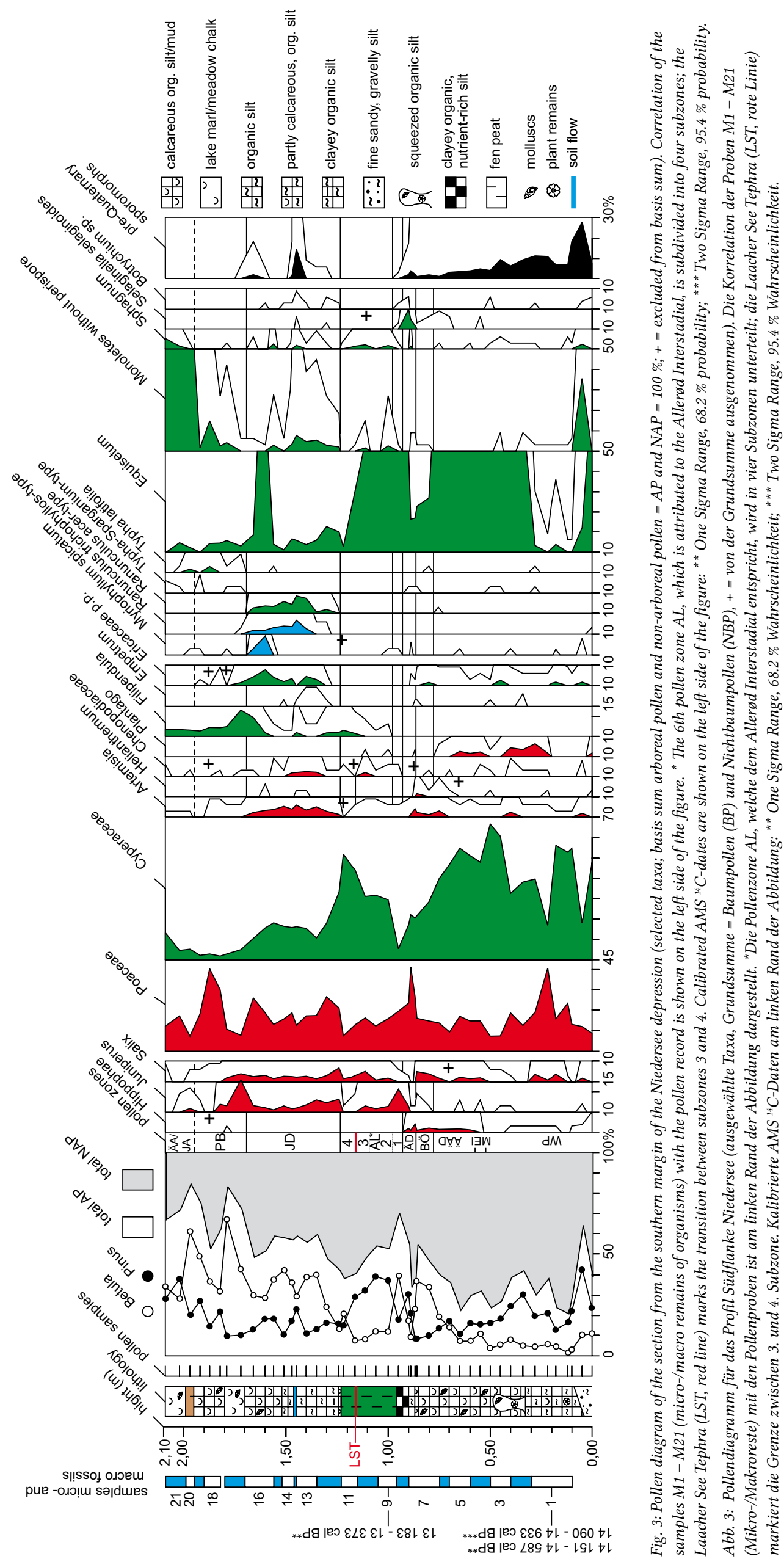




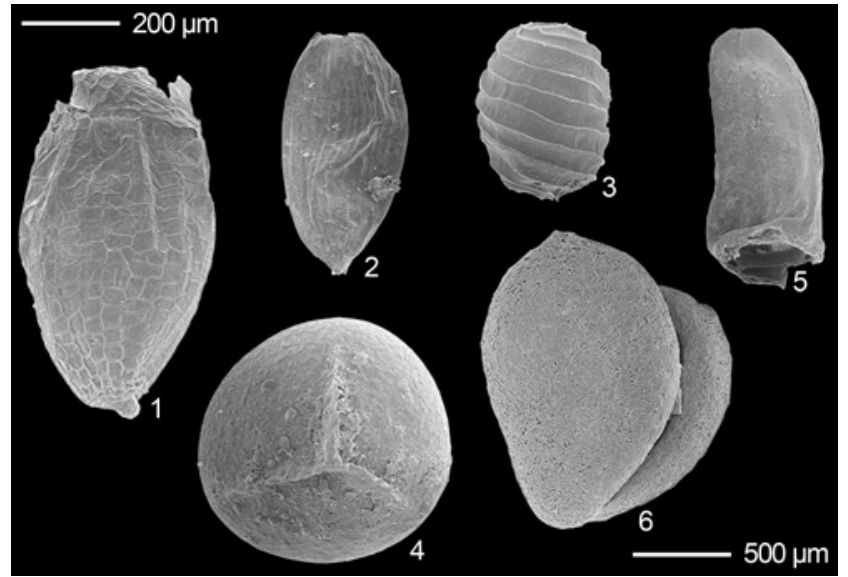

Fig. 4: Selected plant macro remains. 1. Seed of funcus castaneus, sample M1. 2. Seed of Juncus sp., sample M1. 3. Oospore of Charales, sample M2. 4. Megaspore of Selaginella selaginoides, sample M8. 5. Bud scale of Salix sp., sample M2. 6. Fruitstone of Potamogeton filiformis, sample M2. $200 \mu \mathrm{m}$ scale for Fig. 1-4; 500 um scale for Fig. 5, 6.

Abb. 4: Ausgewählte Makroreste von Pflanzen. 1. Same von funcus castaneus, Probe M1; 2. Same von funcus sp., Probe M1; 3. Oospore der Charales, Probe M2; 4. Megaspore von Selaginella selaginoides, Probe M8; 5. Knospenschuppe von Salix sp., Probe M2; 6. Steinkern von Potamogeton filiformis, Probe M2. $200 \mu \mathrm{m}$ Maßstab für Fig. 1-4; 500 um Maßstab für Fig. 5, 6.

(pollen of Typha-Sparganium-type) and idioblasts of water lilies (Nymphaeaceae). Evidence of green algae, dominated by the two taxa Pediastrum kawraiskyi and Pediastrum boryanum, and rests of planarians (Turbellaria) are also documented through the pollen analyses.

The sample M1 (0.1-0.3 m over base line, Fig. 3) provided several macrofossils of terrestrial, littoral and aquatic plants. Particularly frequent are the bud scales of the dwarf willows (Salix spp., Fig. 4). It seems that these shrubby dwarf willows were the dominant woody plants in the vicinity of the Niedersee. The dwarf birch Betula nana is only recorded by one nutlet suggesting that this taxon was apparently not frequent in the proximate surroundings, and that its preferred habitats were seemingly located farther away. But the recorded macrofossil supports the assumption that the small pollen type from this taxon, which here is proven in greater quantities, is of autochthonous origin. Seeds of rush (funcus castaneus, funcus spp., Fig. 4) and sedges (Carex spp.) are further dominant components. The frequent occurrences of Carex and Funcus seeds correlate well to the high percentages of this pollen type within the pollen diagram indicating that the lake was presumably surrounded by the Cyperaceae/Juncaceae and that these taxa can be clearly regarded as a local and contemporaneous constituent of vegetation. Seeds of spike rush (Eleocharis palustris) and red fescue (Festuca rubra) are proven by single records. Aquatic plants are documented through several fruitstones of the slender-leaved pondweed (Potamogeton filiformis, Fig. 4). The presence of stoneworts is given by one gyrogonite of the Charales, but the rare findings indicate a poor settlement during the initial phase of the Niedersee. The lacking evidence for Myriophyllum spicatum, Typha latifolia, and Nymphaeaceae through macro remains indicates that the recorded pollen/idioblasts of these taxa also stem most likely from reworked material.
Ostracods are only proven by one valve of Cyclocypris ovum and few specimens of Candona candida (Tab. 1).

The mollusc fauna shows also low abundances and diversity in species. Gastropods are only documented by some shells of Stagnicola sp. and Radix balthica (Tab. 1). Bivalves are only represented by few juvenile specimens of pea mussels (Pisidium spp.).

The data indicate that after the retreat of the ice sheet of the Mecklenburg phase ( 17,000 to 15,000 cal. years BP, comp. LiTT et al. 2007) an early colonization of the vicinity of the Niedersee and of the lake itself took place, which is documented by several micro and macro remains of biota. An AMS ${ }^{14} \mathrm{C}$-dating, which was performed on plant material from terrestrial dwarf willows from the lowermost lake sediments (sample M1, KIA 33255), confirmed the assumption of an early colonization. Nevertheless, the date calibrated to IntCal09 (REIMER et al. 2009) covers a broad time interval ranging from 14,151-14,587 cal. BP (One Sigma Range, $68.2 \%$ probability) and 14,090-14,933 cal. BP (Two Sigma Range, $95.4 \%$ probability) respectively, which is attributed to a plateau of the calibration curve in this time. The broad time range does not allow for an accurate age determination, the sample can be assigned both to the end of the Weichselian Pleniglacial and to the Meiendorf Interstadial of the Weichselian Late Glacial, whose onset in Northern Germany is defined at 14,450 varve years BP (comp. LitT \& STEBICH 1999; LitT et al. 2007).

But due to the pollen and macrofossil record that reflects subarctic conditions and which is comparable to other Weichselian Pleniglacial records in Northern Germany (STRAHL 2005; KRIENKe et al. 2006; Kossler 2010), the lowermost section interval is considered as still belonging to the Weichselian Pleniglacial. Evidence for summer temperatures are given by the presence of the dwarf birch $B$. nana, which requires a mean July temperature of at least $7{ }^{\circ} \mathrm{C}$ (ISARIN $\&$ BOHNCKE 1999). With the calcareous soils preferring funcus castaneus a distinctive plant of the subarctic tundra is proven, which seems to be typical for the Weichselian Pleniglacial of Northern Germany (KRIENKE et al. 2006; KossLer 2010). It is a typical pioneer plant of wet and immature soils (CASPER \& KraUSCH 1981; KienAST 2002). First development of a sedge/horsetail reed at the edges of the Niedersee is indicated by the frequent occurrences of seeds/pollen of Cyperaceae and spores of Equisetum. In general, the composition of the pollen record and the macro remains of terrestrial plants suggest the predominance of tundra-steppe communities with subordinately occurring woody taxa. Such vegetative ecotypes indicate generally cold, harsh and unstable climatic conditions, which affected the aquatic habitats as well.

Abundances and diversity of aquatic biota are low, which reflects nutrient poor and cold condition during the initial phase of the Niedersee. Moreover, during the long winter time the shallow Niedersee was most probably frozen solid avoiding the colonization with stable communities. The occurring Potamogeton filiformis is characteristic for cold-oligotrophic, hard water lakes and well-known from other Weichselian Pleniglacial sites (KRIENKE et al. 2006; KosSler 2010). According to Kolstrup (1980), a mean July temperature of at least $8{ }^{\circ} \mathrm{C}$ is necessary for the occurrence of this circumpolar pondweed. Only few valves of ostra- 
Tab. 1: Occurrence of the molluscs ( ${ }^{*}$ with the exception of the Succineidae only aquatic taxa) and ostracods within the sedimentary record of the Niedersee, samples M1-M21. Samples are correlated with their stratigraphic classification.

Tab. 1: Nachweis von Ostracoden und Mollusken ( ${ }^{*}$ mit Ausnahme der Succineidae ausschließlich aquatische Taxa) in den Proben aus dem Profil Südflanke Niedersee.

\begin{tabular}{|c|c|c|c|c|c|c|c|c|c|c|c|c|c|c|c|c|c|c|c|c|c|c|}
\hline \multicolumn{2}{|r|}{$\begin{array}{c}\text { Molluscs and ostracods from } \\
\text { the Niedersee section }\end{array}$} & $\frac{\sum_{3}^{n}}{\Sigma}$ & $\begin{array}{l}\bar{W} \\
\sum_{\Sigma}^{\prime \prime} \\
N\end{array}$ & $\begin{array}{l}\bar{W} \\
\sum_{I I} \\
\sum\end{array}$ & $\begin{array}{l}\sum_{1 I}^{\infty} \\
\dot{\Sigma} \\
\Sigma\end{array}$ & $\begin{array}{l}0 \\
: \frac{1}{4} \\
11 \\
10 \\
\Sigma\end{array}$ & 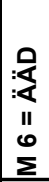 & $\begin{array}{l}\text { : } \\
: 0 \\
: 0 \\
0 \\
\text { II } \\
\\
\Sigma\end{array}$ & $\begin{array}{l}0 \\
: 11 \\
\infty \\
\Sigma\end{array}$ & $\begin{array}{l}\frac{1}{4} \\
\text { II } \\
\text { o } \\
\Sigma\end{array}$ & $\begin{array}{l}\frac{1}{4} \\
\text { II } \\
\text { 을 } \\
\Sigma\end{array}$ & $\begin{array}{l}\frac{1}{4} \\
\text { II } \\
\check{\Sigma} \\
\Sigma\end{array}$ & $\begin{array}{l}\stackrel{9}{2} \\
\stackrel{11}{N} \\
\stackrel{\Sigma}{\Sigma}\end{array}$ & $\begin{array}{l}9 \\
\text { II } \\
\stackrel{m}{\Sigma} \\
\Sigma\end{array}$ & $\begin{array}{l}\stackrel{0}{J} \\
\text { II } \\
\dot{\Sigma} \\
\Sigma\end{array}$ & $\begin{array}{l}9 \\
\text { II } \\
\text { م } \\
\Sigma \\
\Sigma\end{array}$ & $\begin{array}{l}0 \\
\text { II } \\
0 \\
0 \\
\Sigma\end{array}$ & $\begin{array}{l}\mathbf{m} \\
\text { II } \\
\\
\Sigma \\
\Sigma\end{array}$ & $\begin{array}{l}\boldsymbol{m} \\
\mathbf{Q} \\
\text { II } \\
\infty \\
\stackrel{\infty}{\Sigma}\end{array}$ & 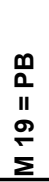 & 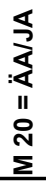 & 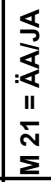 \\
\hline \multirow{17}{*}{ 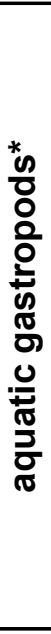 } & Radix balthica & $\mathbf{x}$ & $\mathbf{x}$ & $\mathbf{x}$ & $\mathbf{x}$ & $\mathbf{x}$ & $\mathbf{x}$ & $\mathbf{x}$ & & & & & & & $\mathbf{x}$ & $\mathbf{x}$ & $\mathbf{x}$ & $\mathbf{x}$ & $\mathbf{x}$ & $\mathbf{x}$ & & \\
\hline & Lymnaea stagnalis & & & & & & & & & & & & & & & $\mathbf{x}$ & $\mathbf{x}$ & $\mathbf{x}$ & $\mathbf{x}$ & $\mathbf{x}$ & & \\
\hline & Stagnicola indet. & $\mathbf{x}$ & $\mathbf{x}$ & $\mathbf{x}$ & $\mathbf{x}$ & $\mathbf{x}$ & $\mathbf{x}$ & $\mathbf{x}$ & & & & & & & & & & & & & & \\
\hline & Galba truncatula & & & & & & & & & & & & & & & & & & & & & $\mathbf{x}$ \\
\hline & Myxas glutinosa & & & & & & & & & & & & & & & $\mathbf{x}$ & $\mathbf{x}$ & & & $\mathbf{x}$ & & \\
\hline & Acroloxus lacustris & & & & & & & & & & & & & & & & & $\mathbf{x}$ & $\mathbf{x}$ & $\mathbf{x}$ & & \\
\hline & Valvata aff. alpestris & & & & & & & & & & & & & & $\mathbf{x}$ & $\mathbf{x}$ & $\mathbf{x}$ & $\overline{\mathbf{x}}$ & $\overline{\mathbf{x}}$ & $\overline{\mathbf{x}}$ & & \\
\hline & Valvata cristata & & & & & & & & & & & & & & & $\bar{x}$ & $\bar{x}$ & $\overline{\mathbf{x}}$ & $\bar{x}$ & $\bar{x}$ & & $\mathbf{x}$ \\
\hline & Gyraulus (A.) crista & & & & & & & $\mathbf{x}$ & & & & & $\mathbf{x}$ & & & & $\mathbf{x}$ & $\mathbf{x}$ & $\mathbf{x}$ & $\mathbf{x}$ & & \\
\hline & Gyraulus laevis & & & & & & & $\mathbf{x}$ & & & & & & & & & $\mathbf{x}$ & $\mathbf{x}$ & $\mathbf{x}$ & $\mathbf{x}$ & & \\
\hline & Hippeutis complanatus & & & & & & & & & & & & & & & & $\mathbf{x}$ & $\mathbf{x}$ & $\mathbf{x}$ & $\bar{x}$ & & \\
\hline & Anisus vortex & & & & & & & & & & & & & & & & & $\mathbf{x}$ & $\mathbf{x}$ & $\mathbf{x}$ & & \\
\hline & Anisus leucostoma & & & & & & & & & & & & & & & & & & & & & $\mathbf{x}$ \\
\hline & Bathyomphalus contortus & & & & & & & & & & & & & & & & & $\mathbf{x}$ & $\mathbf{x}$ & & & \\
\hline & Segmentina nitida & & & & & & & & & & & & & & & & & & & & & $\mathbf{x}$ \\
\hline & Aplexa hypnorum & & & & & & & & & & & & & & & & & & & & & $\mathbf{x}$ \\
\hline & Succineidae indet. & & & & & $\mathbf{x}$ & $\mathbf{x}$ & & & & & & & & & & & & & & & $\mathbf{x}$ \\
\hline \multirow{10}{*}{$\begin{array}{l}\frac{0}{\Phi} \\
\frac{2}{\pi} \\
\frac{2}{2}\end{array}$} & Sphaerium corneum & & & & & & & & & & & & & & & $\mathbf{x}$ & $\mathbf{x}$ & $\mathbf{x}$ & $\mathbf{x}$ & $\mathbf{x}$ & & \\
\hline & Pisidium casertanum & & & $\mathbf{x}$ & $\mathbf{x}$ & $\mathbf{x}$ & $\mathbf{x}$ & $\mathbf{x}$ & & & & & & & & & $\mathbf{x}$ & $\mathbf{x}$ & $\mathbf{x}$ & $\mathbf{x}$ & & $\mathbf{x}$ \\
\hline & Pisidium hibernicum & & & & & $\mathbf{x}$ & $\mathbf{x}$ & $\mathbf{x}$ & & & & & & & & & $\mathbf{x}$ & & & & & \\
\hline & Pisidium lilljeborgi & & $\mathbf{x}$ & $\mathbf{x}$ & $\mathbf{x}$ & $\bar{x}$ & $\bar{x}$ & & & & & & & & & & & & & & & \\
\hline & Pisidium nitidum & & & $\mathbf{x}$ & $\overline{\mathbf{x}}$ & $\overline{\mathbf{x}}$ & $\mathbf{x}$ & $\mathbf{x}$ & & & & & & & & $\mathbf{x}$ & $\mathbf{x}$ & $\mathbf{x}$ & $\mathbf{x}$ & $\mathbf{x}$ & & \\
\hline & Pisidium milium & & $\mathbf{x}$ & $\mathbf{x}$ & $\mathbf{x}$ & $\mathbf{x}$ & $\mathbf{x}$ & $\mathbf{x}$ & & & & & & & & & $\mathbf{x}$ & $\mathbf{x}$ & $\mathbf{x}$ & $\mathbf{x}$ & & \\
\hline & Pisidium obtusale & & & & & & & & & & & & & & & & & & & & & $\mathbf{x}$ \\
\hline & P. obtusale f. lapponicum & & & $\mathbf{x}$ & $\mathbf{x}$ & $\mathbf{x}$ & $\mathbf{x}$ & $\mathbf{x}$ & & & & & & & & & $\mathbf{x}$ & & & & & \\
\hline & Pisidium pulchellum & & & & & & & & & & & & & & & & $\mathbf{x}$ & $\mathbf{x}$ & & & & \\
\hline & Pisidium subtruncatum & & & & & & $\mathbf{x}$ & & & & & & & & & $\mathbf{x}$ & $\mathbf{x}$ & $\mathbf{x}$ & $\mathbf{x}$ & & & \\
\hline \multirow{23}{*}{$\begin{array}{l}\frac{n}{0} \\
0 \\
0 \\
\frac{0}{0} \\
\frac{0}{0}\end{array}$} & Candona candida & $\mathbf{x}$ & $\mathbf{x}$ & $\mathbf{x}$ & $\mathbf{x}$ & $\mathbf{x}$ & $\mathbf{x}$ & $\mathbf{x}$ & & & & & $\mathbf{x}$ & & & $\mathbf{x}$ & $\mathbf{x}$ & $\mathbf{x}$ & $\mathbf{x}$ & $\mathbf{x}$ & $\mathbf{x}$ & $\mathbf{x}$ \\
\hline & Pseudocandona compressa-gr. & & & & & & & & & & & & & & & $\mathbf{x}$ & $\mathbf{x}$ & $\mathbf{x}$ & $\mathbf{x}$ & $\mathbf{x}$ & $\mathbf{x}$ & \\
\hline & Pseudocandona sucki & & & & & & & & & & & & & & & & & & & & & $\mathbf{x}$ \\
\hline & Fabaeformiscandona protzi & & & & & & & & & & & & & & & & $\mathbf{x}$ & $\mathbf{x}$ & $\mathbf{x}$ & & & \\
\hline & Cypria ophthalmica & & & & & & & & & & & & & & & & & $\mathbf{x}$ & $\mathbf{x}$ & $\mathbf{x}$ & & \\
\hline & Cyclocypris serena & & & & & & & & & & & & & & & & $\mathbf{x}$ & $\mathbf{x}$ & $\mathbf{x}$ & & & \\
\hline & Cyclocypris laevis & & & & & & & & & & & & & & & & & $\mathbf{x}$ & $\mathbf{x}$ & $\mathbf{x}$ & & \\
\hline & Cyclocypris ovum & $\mathbf{x}$ & $\mathbf{x}$ & $\mathbf{x}$ & $\mathbf{x}$ & $\mathbf{x}$ & $\mathbf{x}$ & $\mathbf{x}$ & & & & & $\mathbf{x}$ & & & $\mathbf{x}$ & $\mathbf{x}$ & $\mathbf{x}$ & $\mathbf{x}$ & $\mathbf{x}$ & & \\
\hline & Ilyocypris indet. & & & & & & $\mathbf{x}$ & $\mathbf{x}$ & & & & & & & & & & & & & & \\
\hline & Ilyocypris cf. getica & & $\mathbf{x}$ & $\mathbf{x}$ & $\mathbf{x}$ & $\mathbf{x}$ & $\mathbf{x}$ & & & & & & & & & & & & & & & \\
\hline & Ilyocypris bradyi & & & & & $\mathbf{x}$ & $\mathbf{x}$ & & & & & & & & & & & & & & & \\
\hline & Notodromas monacha & & & & & & & & & & & & & & & & & $\mathbf{x}$ & $\mathbf{x}$ & $\mathbf{x}$ & & \\
\hline & Cyprois marginata & & $\mathbf{x}$ & $\mathbf{x}$ & $\mathbf{x}$ & $\mathbf{x}$ & $\mathbf{x}$ & & & & & & & & & & & & & & & \\
\hline & Cypris pubera & & $\mathbf{x}$ & $\mathbf{x}$ & $\mathbf{x}$ & $\mathbf{x}$ & $\mathbf{x}$ & $\mathbf{x}$ & & & & & & & & & & & & & & \\
\hline & Eucypris dulcifons & & $\mathbf{x}$ & $\mathbf{x}$ & $\mathbf{x}$ & $\mathbf{x}$ & $\mathbf{x}$ & & & & & & & & & & & & & & & \\
\hline & Eucypris pigra & & & & & & & & & & & & & & & & & & & & & $\mathbf{x}$ \\
\hline & Cryptocandona vavrai & & & & & & & & & & & & & & & & & & & & & $\mathbf{x}$ \\
\hline & Herpetocypris reptans & & & & $\mathbf{x}$ & $\mathbf{x}$ & $\mathbf{x}$ & $\mathbf{x}$ & & & & & & & & & $\mathbf{x}$ & $\mathbf{x}$ & $\mathbf{x}$ & $\mathbf{x}$ & & \\
\hline & Heterocypris incongruens & & $\mathbf{x}$ & $\mathbf{x}$ & $\mathbf{x}$ & $\mathbf{x}$ & $\mathbf{x}$ & $\mathbf{x}$ & & & & & & & & & & & & & & \\
\hline & Cypridopsis vidua & & & $\mathbf{x}$ & $\mathbf{x}$ & $\mathbf{x}$ & $\mathbf{x}$ & $\mathbf{x}$ & & & & & & & & & $\mathbf{x}$ & $\mathbf{x}$ & $\mathbf{x}$ & $\mathbf{x}$ & & \\
\hline & Potamocypris arcuata & & $\mathbf{x}$ & $\mathbf{x}$ & $\mathbf{x}$ & $\mathbf{x}$ & $\mathbf{x}$ & $\mathbf{x}$ & & & & & & & & & & & & & & \\
\hline & Potamocypris villosa & & $\mathbf{x}$ & $\mathbf{x}$ & $\mathbf{x}$ & $\mathbf{x}$ & $\mathbf{x}$ & $\mathbf{x}$ & & & & & \begin{tabular}{|l|}
$x$ \\
\end{tabular} & & & & $\mathbf{x}$ & $\mathbf{x}$ & $\mathbf{x}$ & & & \\
\hline & Limnocythere inopinata & & & & & & & $\mathbf{x}$ & & & & & & & & $\mathbf{x}$ & $\mathbf{x}$ & $\mathbf{x}$ & $\mathbf{x}$ & $\mathbf{x}$ & & \\
\hline
\end{tabular}

cods and molluscs are proven. The most frequently found ostracod C. candida is a well-known taxon from Weichselian Pleni- and Late Glacial deposits (e.g. Mania 1967; Frenzel \& Viehberg 2004; Krienke et al. 2006; Frenzel,
Keyser \& Viehberg 2010; Kossler 2010). Today it is also a widespread and frequent ostracod in arctic lakes (ALM 1916). It can occur in a wide temperature range, but it has its optimum at $7.2{ }^{\circ} \mathrm{C}$ water temperature (VIEHBERg 2006). 
The gastropod $R$. balthica can be regarded as pioneer taxon appearing directly in water bodies after the retreat of the glaciers (ØKLAND 1990; KRIENKE et al. 2006).

For this section interval a mean July temperature of at least $7-8{ }^{\circ} \mathrm{C}$ can be reconstructed, which indicates subarctic climatic conditions at this time. The climatic reconstruction supports the assumption that the pollen of arboreal (e.g. Corylus, Carpinus) and non-arboreal taxa, which prefer warmer conditions (e.g. Typha latifolia, which according to IsARIN \& BOHNCKE (1999) requires a mean July temperature of at least $\left.13{ }^{\circ} \mathrm{C}\right)$, stem from older reworked material.

\subsubsection{Section interval 0.33-0.6 m: Meiendorf Interstadial}

The sedimentary succession of this section interval is characterized by greyish-white calcareous organic silts, which are partially rich in molluscs. Oxygenized spots, which occur all over, are typical. A specific sedimentary feature can be observed between $0.33-0.49 \mathrm{~m}$, here the bluish-grey silts of the Weichselian Pleniglacial are squeezed into the younger calcareous organic silts due to processes of gravity.

The pollen record of this section interval firstly resembles the previous one and is therefore not very expressive. Changes within the pollen record indicating the climatic warming of the Meiendorf Interstadial, the first time interval of the Weichselian Late Glacial (14,450 to 13,800 varve years BP, comp. LiTT et al. 2007), are only documented between $0.5-0.6 \mathrm{~m}$ of section. The pollen diagram shows in this part (2nd pollen zone = MEI in Fig. 3) a slight increase of Betula, the onset of a continuous Hippophaë/Salix-graph and decreasing values of reworked Pinus and pre-Quaternary sporomorphs (Fig. 3). In general, the herbaceous taxa, particularly Artemisia and Plantago ( $<1 \%$ ), are affected by a distinct decline as well. In contrast, the local flora is still dominated by Cyperaceae and Equisetum, which pollen/spores record covers the arboreal pollen record simulating subordinated values of the woody taxa. Compared to the plant pollen record, the green algae demonstrate that this organism group clearly reacts earlier than the terrestrial plants. With the onset of the sedimentation of calcareous organic silts from $0.33 \mathrm{~m}$ onward, the two taxa Pediastrum kawraiskyi and Pediastrum boryanum show a distinct decline in abundances. This applies to the remains of planarians (Turbellaria) as well.

The onset of the climatic amelioration is documented somewhat earlier by the plant macro remains than by the pollen record. The record of plant remains from the sample M2 (0.3-0.4 m), M3 (0.4-0.5 m), and M4 (0.5-0.6 $\mathrm{m})$ indicate remarkable changes in the vicinity of the Niedersee. Whereas bud scales of dwarf willow and funcus/ Carex-seeds were frequent in the lowermost layers of the Niedersee section (see 3.1.1.1, sample M1 of Weichselian Pleniglacial), there are only few proofs for dwarf willows and for seeds of Juncus/Carex in the following samples M2, M3 and M4. Now, plant remains are mainly composed of seeds of Eleocharis palustris and indeterminable plant debris. The frequent seeds of E. palustris indicate the development of a spike rush reed at the edges of the Niedersee. Several fruitstones of Potamogeton filiformis (Fig. 4) document firstly the continuing dominance of this pondweed within the aquatic flora, but increasing number of oospores (Fig. 4) and gyrogonites of stoneworts reflect the expansion of this organism group as well. Then, with the sample M3, a distinct shift from a Potamogeton-lake to a Chara-lake is recognisable. Now, numerous gyrogonites dominate over infrequent fruitstones of $P$. filiformis. This shift to a Charalake is also reflected in the sediments, because these are now mainly composed of calcareous particles of the stoneworts, which indicate a dense colonization of the lake bottom by this organism group.

The sample M2 (0.3-0.4 m) provided an ostracod fauna, which is characterized by a distinctly increased diversity and great abundances as well (Tab. 1). Beside the already proven $C$. candida and C. ovum, Heterocypris incongruens, Ilyocypris cf. getica, Cyprois marginata, Cypris pubera, Potamocypris villosa, Potamocypris arcuata and Eucypris dulcifons appear for the first time (Fig. 5). The migration of Cypridopsis vidua and Herpetocypris reptans into the habitat is proven with a delay in time. The former appears in sample M3 and the latter in sample M4 for the first time.

Within this section interval, the diversity and the abundances of the mollusc fauna increased remarkably (Tab. 1). Although the gastropod fauna of sample M2, M3 and M4 is still characterized by a low diversity, the abundances are distinctly higher. The dominating taxon within the gastropod fauna is clearly Radix balthica, but sample M3 shows a slight increase in abundances of Stagnicola sp. In contrast, the bivalve fauna is characterized by an increase both in diversity and in abundances. Whereas in sample M2 the pea mussels are firstly represented by several shells of Pisidium milium and Pisidium lilljeborgi, the pea mussels $P$. nitidum, $P$. obtusale f. lapponicum and P. casertanum appear additionally within the habitat (sample M3 and M4).

The present data show that the amelioration of the climate, which indicates the onset of the Meiendorf Interstadial, is rather revealed through the aquatic organisms and macro remains of plants than through the pollen record. This phenomenon could be often observed from different sites in northern Germany (e.g. STRAHL 2005; KoSSLER 2010) and this applies here for the onset of the Meiendorf Interstadial as well. Although the resolution of sample M2 does not allow for determining the exact position of the boundary Weichselian Pleniglacial/Meiendorf Interstadial, it is most likely that the onset of the climatic amelioration is reflected in the sediments from $0.33 \mathrm{~m}$ onward (see Fig. 2,3), if the changes in sedimentation and the decline in the planktonic green algae as well as planarians are taken into account.

The climatic amelioration led to a remarkable increase in diversity and abundance, which is especially documented within the aquatic biota. Nevertheless, the development of a spike rush reed at the edges of the Niedersee give evidence for rising summer temperatures. According to Kolstrup (1980), a mean July temperature of at least $10{ }^{\circ} \mathrm{C}$ is necessary for the successful expansion of E. palustris.

Related to the climatic amelioration, particularly the stoneworts, ostracods and bivalves show that the Niedersee developed into a stable and suitable habitat for these organisms. Whereas C. candida and Eucypris dulcifons are cold condition preferring ostracods that are proven from several Weichselian Pleniglacial and Late Glacial 


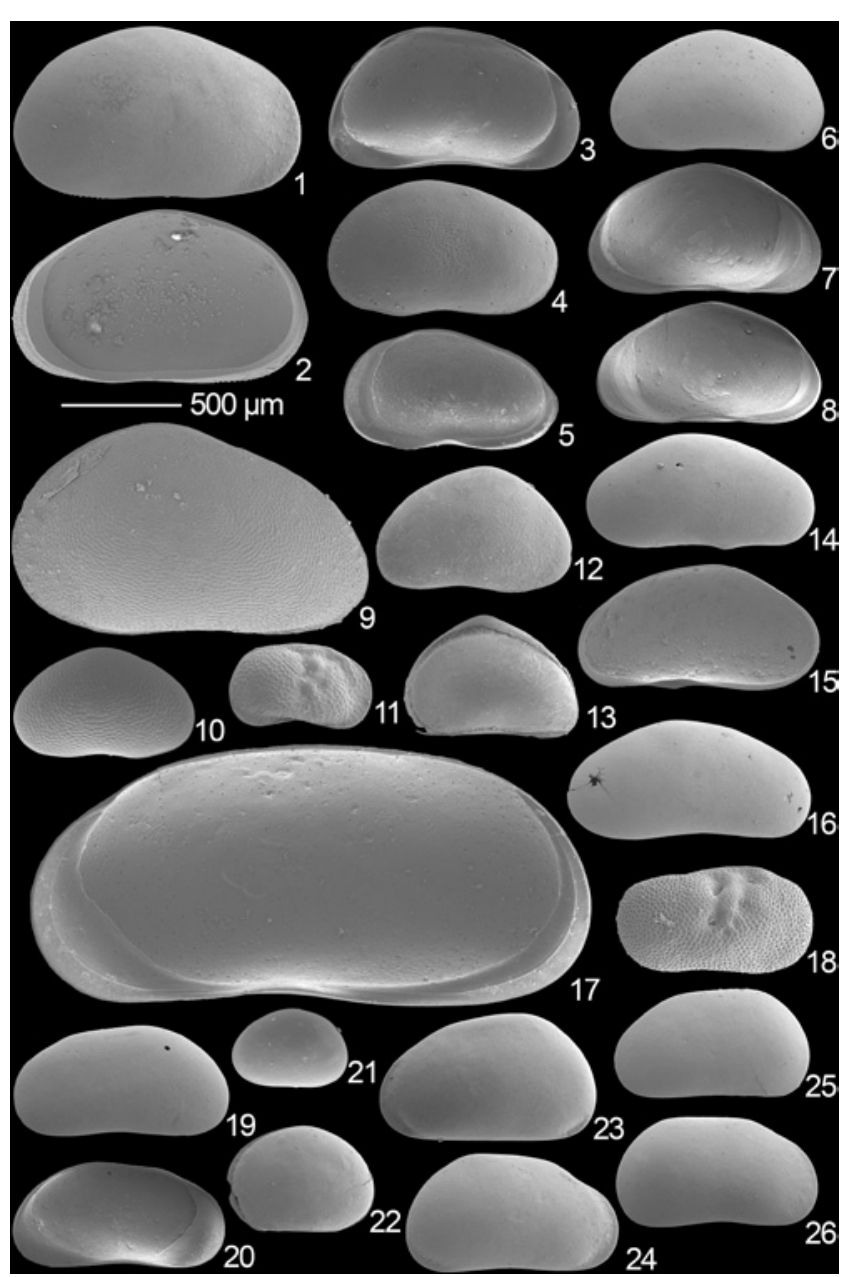

Fig. 5: Selected ostracods from the Niedersee section. 1. - 2. Heterocypris incongruens, sample M2: 1. right valve, 2. internal view of a right valve. 3. Candona candida, sample M2: internal view of a left valve. 4. - 5. Eucypris dulcifons, sample M2: 4. left valve, 5. internal view of a right valve. 6. -8 . Eucypris pigra, sample M21: 6. right valve, 7. internal view of a left valve, 8. internal view of a right valve. 9. Cypris pubera, sample M2: juvenile left valve. 10. Cypridopsis vidua, sample M3: right valve. 11. Limnocythere inopinata, sample M17: right valve. 12. Potamocypris arcuata, sample M2: right valve, surface dotted with spots. 13. Potamocypris villosa, sample M2: carapace in lateral view, view on the left valve, surface smoth. 14. - 15. Fabaeformiscandona protzi; sample M17: 14. right valve of a male with a distinct expansion in the mouth region, 15. internal view of a right valve, 16. right valve of a female without distinct expansion in the mouth region. 17. Herpetocypris reptans, sample M4: internal view of a right valve. 18. Ilyocypris cf. getica, sample M2: right valve. 19. - 20. Cryptocandona vavrai, sample M21: 19. left valve, 20. internal view of a left valve. 21. Cyclocypris ovum, sample M2: left valve. 22. Notodromas monacha, sample M17: left valve. 23. - 24. Pseudocandona compressa-Gruppe, sample M17: 23. left valve, 24. right valve. 25. - 26. Pseudocandona sucki, sample M21: 25. left valve, 26. right valve. Scale for all figures.

Abb. 5: Ausgewählte Ostracoden aus dem Profil Südflanke Niedersee. 1. - 2. Heterocypris incongruens, Probe M2: 1. rechte Klappe, 2. Innenansicht einer rechten Klappe. 3. Candona candida, Probe M2: Innenansicht einer linken Klappe. 4. - 5., Eucypris dulcifons, Probe M2: 4. linke Klappe, 5. Innenansicht einer rechten Klappe. 6. - 8. Eucypris pigra, Probe M21: 6. rechte Klappe, 7. Innenansicht einer linken Klappe, 8. Innenansicht einer rechten Klappe. 9. Cypris pubera, Probe M2: juvenile linke Klappe. 10. Cypridopsis vidua, Probe M3: rechte Klappe. 11. Limnocythere inopinata, Probe M17: rechte Klappe. 12. Potamocypris arcuata, Probe M2: rechte Klappe, Oberfläche mit Grübchen. 13. Potamocypris villosa, Probe M2: doppelklappiges Exemplar, Oberfläche glatt. 14. - 15. Fabaeformiscandona protzi; Probe M17: 14. rechte Klappe eines männlichen Exemplars mit charakteristischer Wölbung am unteren Rand der Klappe im Bereich der Mundregion, 15. Innenansicht einer rechten Klappe, 16. rechte Klappe eines weiblichen Exemplars ohne Wölbung am unteren Rand der Klappe im Bereich der Mundregion. 17. Herpetocypris reptans, Probe M4: Innenansicht einer rechten Klappe. 18. Ilyocypris cf. getica, Probe M2: rechte Klappe. 19. - 20. Cryptocandona vavrai, Probe M21: 19. linke Klappe, 20. Innenansicht einer linken Klappe. 21. Cyclocypris ovum, Probe M2: linke Klappe. 22. Notodromas monacha, M17: linke Klappe. 23. - 24. Pseudocandona compressa-Gruppe, Probe M17: 23. linke Klappe, 24. rechte Klappe. 25. - 26. Pseudocandona sucki, Probe M21: 25. linke Klappe, 26. rechte Klappe. Maßstab gilt für alle Exemplare.

sites (Fuhrmann, Schirrmeister \& Pietrzeniuk 1997; KOSSLER 2010), the presence of the mesothermic Cyprois marginata and Cypris pubera indicates clearly increasing temperatures during the summer. The occurrence of $I$. cf. getica gives evidence of rising temperatures as well. According to MeIsch, FuHrmann \& Wouters (1996), I. getica is most likely stenothermal for a water temperature range of $10-15{ }^{\circ} \mathrm{C}$. The appearance of Herpetocypris reptans, whose preferred diet are particles of stoneworts and Eleocharis palustris (BENZIE 1989), correlates well with the increasing expansion of these plant taxa. Like the ostracods, the bivalves benefit from the improvement of living conditions. The eurytopic bivalves Pisidium casertanum and P. nitidum are common and widespread species within the European faunal realm and occur in a wide range of aquatic habitats (GLÖER \& MEIER-BrooK 2003). Their present distributions north of the arctic cycle and several fossil records from colder phases of the Pleistocene (e.g. KuIPER 1968; KossLer 2010) show their potential to tolerate colder climatic conditions. A typical northern faunal element of arctic and subarctic regions is documented through shells of $P$. obtusale f. lapponicum. Today, the present range of this species is restricted to northern Scandinavia. In contrast to the present situation, this pea mussel was also distributed in Central Europe during colder phases of the Pleistocene (e.g. KuIPER 1968; PIECHOCKI 1989). Another species which is often found in fossil subarctic assemblages is Pisidium lilljeborgi (KuIPER 1968). P. lilljeborgi is a stenoecious pea mussel restricted to oxygen-rich, oligotrophic, and stagnant water bodies (e.g. Piесноскі 1989), whose present distribution in Central Europe is only shown in larger lakes. But according to TuRner et al. (1998) and HoEk et al. (1999), it could also occur in smaller lakes and ponds during colder climatic phases.

The climatic amelioration of the Meiendorf Interstadial clearly led to increasing summer temperatures with mean July temperatures reaching $10{ }^{\circ} \mathrm{C}$ and seemingly, in some years, slightly more. According to MAtveyeva (1994) this corresponds to the conditions of the subarctic southern tundra. Subarctic faunal elements within the fossil record support this reconstruction. The lack of macro remains of birch trees gives evidence that the climatic warming of the Meiendorf Interstadial was apparently not warm enough for the spread of birch trees (see discussion in 3.1.1.4).

\subsubsection{Section interval 0.6-0.75 m: Oldest Dryas}

The sedimentation of the greyish-white calcareous organic silts, which started already with the onset of the Meiendorf Interstadial (see 3.1.1.2) continued during the whole section interval. 
A climatic deterioration is proven by the pollen record. The changes within the pollen record allow for defining the 3rd pollen zone, which is attributed to the Oldest Dryas (= Ä̈D in Fig. 3). This pollen zone reveals a decrease in Betula percentages $(<10 \%)$, a significant expansion of Hippophä̈ rhamnoides $(>1 \%)$ and, again, an increase in herbaceous taxa and grasses, which especially concerns Plantago, subordinately Artemisia, Ericaceae p.p. and at first the local floral element of the Cyperaceae. But then in the course of the Oldest Dryas, a distinct decrease of the Cyperaceae is observable. Reworked sporomorphs of pre-Quaternary age and of older Quaternary interglacials as well as pollen of Pinus (reworked/possibly long-distance transport) are still relevant, but generally declining. A first noteworthy expansion of Selaginella is indicated towards the top of the pollen zone.

The record of macro plant remains of samples M5 $(0.6-0.7 \mathrm{~m})$ and M6 $(0.7-0.75 \mathrm{~m})$, which correspond to the Oldest Dryas (Fig. 3), is mainly related to the aquatic flora. The poor record of terrestrial plants (i.e., only indeterminable terrestrial plant debris, one nutlet of Eleocharis palustris and only one fragment of a bicarpelate seed of Carex sp.) does not allow for drawing any conclusions about the local development of vegetation. As before, the aquatic flora is dominated by stoneworts and the subordinated occurrence of pondweeds, which is indicated by numerous gyrogonites, particles of the lime encrusted stalks and by some fruitstones of Potamogeton filiformis.

The sediments are still extremely rich in ostracods. The ostracod fauna of sample M5 and M6 is more or less consistent with the previous fauna in terms of species composition and abundance, only the valves of Candona candida occur in greater quantities indicating slightly colder conditions. For the first time, the colder water temperatures preferring Ilyocypris bradyi is proven within the ostracod assemblages.

The gastropod fauna is still represented by several shells of Radix balthica and Stagnicola sp., but few shells of the terrestrial Succineidae give evidence for the migration of these snails into the habitat. Most species of Succineidae prefer swampy conditions (FRÖMMING 1954; TURNER et al. 1998) and are therefore common in riparian habitats.

Again, the bivalves are documented by a diverse fauna of pea mussels, which is composed of P. nitidum, P. obtusale f. lapponicum, P. casertanum, P. lilljeborgi, P. milium, $P$. subtruncatum and $P$. hibernicum. The two latter species migrate for the first time into the habitat.

The data indicate that the climatic deterioration of the Oldest Dryas (13,800 to 13,670 varve years BP, comp. LITT et al. 2007) led again to an opening of vegetation, which is reflected in the pollen record. The pollen record presented here for the Oldest Dryas corresponds well with the pollen zone Ia (sensu Firbas 1949) from the Rugian section Gingster Haide (LANGe, Jeschke \& KNAPP 1986), even though the latter shows higher values of Hippophä $(<5 \%)$ and of Artemisia.

In contrast, changes within the aquatic fauna/flora are not very pronounced. This led to the conclusion that the cooling of the Oldest Dryas affected more winter temperatures than the summer conditions. In this context, the few proofs of seeds of reed plants (Eleocharis palustris, Carex) and the declining values of pollen percentages of the Cyperaceae can probably be traced back to stronger and longer winter conditions, which led to a decline of the local reed plants due to frost damage and shorter growing seasons. But summer temperatures were high enough to warm up the shallow Niedersee allowing for a very productive development of the stoneworts, the ostracods and the molluscs. The first appearance of the ostracod Ilyocypris bradyi, a generally cooler conditions preferring taxon (NÜCHTERLEIN 1969; JANZ 1994), in combination with the increase of C. candida potentially provides evidence for climatic cooling. Nevertheless, several valves of the mesothermic $C y$ prois marginata, Cypris pubera and Ilyocypris cf. getica demonstrate that the climatic deterioration of the Oldest Dryas did not cause the disappearance of these species. Changes within the mollusc assemblages are particularly demonstrated by the first appearance of the Succineidae and the pea mussels $P$. subtruncatum and $P$. hibernicum. Proofs of the Succineidae are well-known from arctic and subarctic deposits of the Pleistocene (e.g. MANia 1967; FuHrmanN 1973; LožEK 1990). Interestingly, the first appearance of these snails is proven here during the Oldest Dryas, which correlates well with the contemporaneous first appearance of the Succineidae in the sedimentary record of Grimmen (Krienke et al. 2006) and of the Paddenluch (Kossler 2010). Whereas the pea mussel $P$. subtruncatum is known as euryoecious species with a common and widespread distribution, $P$. hibernicum prefers lakes with a bottom of muddy and organic-rich substrate (ZETTLER et al. 2006) indicating that lake productivity was high enough during the growing season to enrich the sediments with organic material.

\subsubsection{Section interval 0.75-0.87 m: Bølling Interstadial}

The sedimentary succession of this section interval is still characterized by greyish-white calcareous organic silts.

This section interval includes the 4th pollen zone, which is attributed to the Bølling Interstadial (= BÖ in Fig. 3). Based on distinctly increasing percentages of Betula within the pollen diagram, the second warming phase of the Weichselian Late Glacial can be recognized. Now, the pollen record of Betula can mainly be traced back to birch trees, and only subordinated to dwarf birches. A slightly increase in funiperus $(<1 \%)$ and Salix is indicated by the pollen record. Different reticulate pollen types of Salix spp. suggest the presence of willow trees next to dwarf willows (Salix polaris-type). Pinus and herbaceous taxa (including Cyperaceae and Equisetum) continue to decline.

Like in the previous samples, the sample M7 (0.75-0.9 m) shows low diversity concerning the macro remains of plants. Beside indeterminable plant debris, the occurrences of several nutlets of Eleocharis palustris give again evidence for a spike rush reed at the edges of the Niedersee. Aquatic flora is still dominated by the stoneworts (i.a. Chara contraria), which are documented through numerous gyrogonites, oospores and stalk remains. Within the pondweeds a replacement of $P$. filiformis through $P$. vaginatus could be observed, but the latter is only proven by few fruitstones indicating that this pondweed occurred subordinately. In addition, the pollen analyses revealed that a distinct in- 
crease in planktonic green algae (Pediastrum boryanum, Botryococcus braunii) took place during the Bølling Interstadial, which can probably be traced back to a changing trophic status of the lake (VAN GEEL 2001).

The ostracod fauna show some changes, which are indicated by the disappearance of C. marginata and Eucypris dulcifons, a distinct decline of $\mathrm{H}$. incongruens and the first appearance of Limnocythere inopinata (Fig. 5). But changes are not so pronounced to draw conclusions that changes within the habitat have significantly affected the ostracod fauna. $C$. candida, $H$. reptans, $C$. ovum still dominate the ostracod assemblages, but C. vidua, C. pubera, Ilyocypris spp., $P$. arcuata and $P$. villosa also occur in greater quantities.

The gastropod fauna is now characterized by a higher diversity, which is caused by the migration of Gyraulus laevis and Gyraulus (A.) crista into the habitat (Tab. 1). The pea mussels are abundant and diverse as before, but fauna is now mainly dominated by P. nitidum, P. milium, P. obtusale f. lapponicum and P. hibernicum, whereas P. casertanum is only documented by few valves. The pea mussel $P$. lilljeborgi is no longer proven.

The warming phase of the Bølling Interstadial (13,670 to 13,540 varve years BP, comp. LITT et al. 2007) is here mainly reflected by the pollen record, which documents the expansion of birches, in this case especially of birch trees. The pollen record of the Niedersee is equivalent with the pollen zone Ib (sensu Firbas 1949) from the Rugian section Gingster Haide in LANGE, JeschKe \& KnApP (1986). The renewed development of a spike rush reed again gives evidence for mean July temperatures of at least $10{ }^{\circ} \mathrm{C}$ (KoLSTRUP 1980). Even though a mean July temperature of $10{ }^{\circ} \mathrm{C}$ can be sufficient for the occurrence of birch trees (BROOKS \& Birks 2000a; RALSKA-Jasiewiczowa et al. 2004), optimal terms for the spread of birch trees require mean July temperature of $\geq 12{ }^{\circ} \mathrm{C}$ (IVERSEN 1954; BIRKS 1993; ODLAND 1996; Brooks \& Birks 2000b). Therefore, taking the spread of the birch trees into account, it can be assumed that mean July temperatures reached at least $12{ }^{\circ} \mathrm{C}$ in this time span.

Related to the climatic amelioration changes in aquatic biota are not very distinct, but give evidence for an increase of lake productivity and in eutrophication. Especially, the disappearance of the oxygen-rich and oligotrophic conditions preferring $P$. lilljeborgi indicates an uprating of the trophic status that led to an increase in biogenic productivity and to an increase in oxygen consumption at the lake bottom. The migration of Gyraulus laevis and Gyraulus (A.) crista into the habitat (Tab. 1) is in contrast to locations further to the south (Grimmen, KRIENKE et al. 2006; Paddenluch, KossLer 2010) slightly time-delayed.

Comparing the pollen data with the range of sample M7 for macro remains and calcareous microfossils (Fig. 3), which was taken in the field related to the sedimentary features, it became evident that the transition between the Bølling Interstadial and the following Older Dryas is located within the sample M7. Nevertheless, most of the sample M7 correlates to the Bølling Interstadial; it provides gaining information concerning the biota of this climatic warming phase.

\subsubsection{Section interval 0.86-0.93 m: Older Dryas}

The lowest part of this section interval up to $0.87 \mathrm{~m}$ is still characterized by the greyish-white calcareous organic silts, but from 0.87 onward a change in sedimentation to greyish organic silts is visible. The sediments pass from $0.88 \mathrm{~m}$ onward into dark brownish, carbonate-free organic silts, and then from $0.9 \mathrm{~m}$ into blackish nutrient-rich, carbonate-free organic silts.

This section interval includes the 5 th pollen zone. Within the pollen record, the second climatic deterioration of the Weichselian Late Glacial, the Older Dryas (= $\ddot{A D}$ in Fig. 3), is reflected. The 5th pollen zone is characterized by a distinct decrease in Betula in favour of shrubby and herbaceous taxa. Particularly, the Poaceae and Hippophaë rhamnoides are showing increasing values, which indicates an opening in vegetation caused by the climatic cooling. Artemisia and Helianthemum show an increase at the beginning of 5th pollen zone. According to the pollen record the local vegetation was mainly composed of Poaceae, $\mathrm{Cy}$ peraceae, Equisetum and Selaginella selaginoides. Remarkably, this pollen zone reveals the highest percentages of Selaginella (more then 10\%). Again, increasing values of reworked older sporomorphs take place together with an increase in Pinus, but a long-distance transport of the latter cannot be excluded either. In addition, the pollen analyses revealed a distinct decrease in planktonic green algae ( $P e-$ diastrum boryanum), which disappeared completely in the course of the Older Dryas.

As mentioned above (see 3.1.1.4), the sample M7 (0.75-0.9 $\mathrm{m}$ ) for macro remains has a range, which passes into the Older Dryas. Based on the resolution of sampling, it is not possible to recognize if there are any changes within the aquatic fauna and flora directly at the transition Bølling Interstadial to Older Dryas. With regard to the sedimentary features it seems that the lake conditions were at first more or less stable beyond the Bølling Interstadial/Older Dryas transition. But the section interval shows from $0.88 \mathrm{~m}$ upward a significant change in sedimentation, which is documented by the onset of dark brownish, calcareous-free organic silts, which later pass into the blackish nutrient-rich, calcareous-free organic silts.

The fossil content of these dark, calcareous-free organic silts (sample M8, 0.9-0.96 m) provided only a few woody fragments and numerous megaspores of Selaginella selaginoides (Fig. 4). The numerous megaspores of $S$. selaginoides correlate with the high percentages of this plant in the pollen record. In contrast, there is no evidence for any aquatic biota, neither flora nor fauna.

The data indicate that the climatic deterioration of the Older Dryas (13,540 to 13,350 varve years BP, comp. LiTT et al. 2007) led to colder and seemingly drier conditions, which is clearly reflected by the sedimentation patterns and the fossil record. The decline of birches is here more obvious than in the corresponding pollen zone Ic (sensu FIRBAS 1949) of the Rugian section Gingster Haide in LANGE, JESCHKE \& KNAPP (1986). The results suggest that a lowering of the water level has affected the Niedersee, which finally caused the development of a spike moss fen. The lack of any fossil remains of aquatic biota within sample M8 and the disappearance of remains of green algae in the pollen 
record support this interpretation. The spike moss prefers wet and calcareous soils and is a typical floral element in the corresponding subarctic/alpine habitats (LANG 1994). According to KolSTRUP $(1979,1980)$ this cold-tolerant plant requires at least a mean July temperature of $7{ }^{\circ} \mathrm{C}$. The impact of the climatic deterioration on the Niedersee is in any case more pronounced than the previous climatic deterioration of the Oldest Dryas. This correlates with the results of the Paddenluch (Brandenburg; KossLer 2010), where the cooling of the Older Dryas had also a stronger effect on the environment.

\subsubsection{Section interval 0.93-1.23 m: Allerød Interstadial}

The sedimentary succession of this section interval shows a change from blackish nutrient-rich, carbonate-free organic silts to blackish minerotrophic woody fen peat at $0.96 \mathrm{~m}$. The record of the Laacher See Tephra (LST) is proven at $1.16 \mathrm{~m}$.

This section interval represents the 6th pollen zone, which is attributed to the Allerød Interstadial, the 3rd warming phase of the Weichselian Late Glacial. The climatic amelioration is reflected in the four subzones of the 6th pollen zone (= $\mathrm{AL}^{*} 1-4$ in Fig. 3$)$. The subzone AL 1 is characterized by a distinct increase of Betula associated with a slightly earlier increase in funiperus and a decrease in heliophilic herbaceous taxa, especially Poaceae, and Artemisia. The non-competitive Hippophaë rhamnoides is no longer proven in the pollen record and is seemingly displaced from the local vegetation. Equisetum and the Cyperaceae show increasing values as well, but the latter do not achieve pre-Allerød percentages. A significant increase of Pinus-pollen indicates the migration of pine and the onset of the second pollen subzone AL 2, whereas the third pollen subzone AL 3 (Gerzensee oscillation, LOTTER et al. 1992; ANDRESEN et al. 2000) is only proven by an indistinct increase of Salix, Poaceae, Chenopodiaceae and Artemisia. The LST marks the transition to the pollen subzone AL 4, which documents again an increase in Betula and the expansion of the thermophilic meadowsweet (Filipendula). The pollen record reveals sporadic findings of pollen of Alnus and gives evidence for the migration of this arboreal tree into the habitat.

The fossil record of samples M9 (0.96-1.05 m), M10 (1.05-1.15 m), and M11 (1.15-1.23 m) mirrors the continuing fen succession. Whereas the plant remains of sample M8 (see 3.1.1.5) reflect the initial phase (Selaginella fen) of the fen succession, a subsequent bush- and tree colonization took place developing a fen carr, which is proven by the peat type and the plant remains of samples M9 and M10. Plant macro remains can mainly be traced back to willows (Salix spp.), subordinately to birch trees, and in a slightly time-delayed manner, we have the first evidence of aspen from the sample M10 (bud scales, most probably Populus tremula). Only a few megaspores of $S$. selaginoides were still proven in sample M9. Instead, few seeds of the stinging nettle (Urtica dioica) and sedges (Carex rostrata), which are proven here for the first time as well, give evidence for the undergrowth. In the following sample M10, there are no more records of Urtica dioica and Carex rostrata, but evidence for Rubus sp. After the deposition of the LST (pollen subzone AL 4), soaking of the site caused by a rising water level is indicated by the development of a Carex rostrata fen. The further expansion of aspen during the late Allerød Interstadial is noteworthy; it is proven by a frequent record of Populus bud scales (sample M11).

No remains of aquatic biota could be detected in the samples M9 and M10, but it cannot be excluded that a small open pond persisted at the deepest point of the Niedersee basin. The proof of one fruitstone of pondweed (Potamogeton sp.) in sample M11 give further evidence for a rising water level during the late Allerød Interstadial.

The development of a fen, whose formation began during the Older Dryas (sample M8) continued during the warmer Allerød Interstadial (13,350 to 12,680 varve years BP, comp. LitT et al. 2007). According to the pollen analyses the transition from Older Dryas to Allerød Interstadial is still located in the blackish nutrient-rich, carbonate-free organic silts, the upper part of sample M8 belongs therefore to the Allerød Interstadial. The pollen dating is confirmed by a further AMS ${ }^{14} \mathrm{C}$-dating (woody fragment of sample M9, KIA 33256), which results in an age of 13,138-13,373 years cal. BP ( $68.2 \%$ probability), corresponding to the older part of the Allerød (Fig. 3), and by the record of the Laacher See Tephra (LST, Fig. 2; see also Kliewe 1996). According to LitT \& STEBICH (1999), the LST has an age of 12,880 varve years BP.

With regard to the previous studies (BOEHM-HARTMANN 1937; STRAHL \& ANDERs unpublished) the Allerød fen peat is also documented within these sections (see Fig. 2). This indicates that the fen development, which can be traced back to a strong lowering of the water level, did not only take place at the edges of the Niedersee but also in the centre part. Whereas BoEHM-HARTMANN (1937) stated only a Holocene age for this fen peat, a review of the published data by STRAHL resulted in a rectified classification ranging back into the Older Dryas (Fig. 2), even though the pollen information given by BoEHM-HARTMANN (1937) was conceived in very general specifications. According to LANGE, JESCHKE \& KNAPP (1986), a first development of peat (pollen zone IIb sensu FIrbAs 1949) also took place in the nearby Credner See (Fig. 1) during the Allerød. The same situation is described by STRAHL \& KedING (1996) from the Rugian Hölle (Fig. 1) and known from several other sites in Mecklenburg-Pomeranian and Brandenburg (e.g. Strahl 2005; Krienke et al. 2006). This indicates that the development of fens, particularly with regard to shallow lakes, in northern Germany is a typical phenomenon of the Allerød Interstadial, which can be traced back to warmer and drier climatic conditions. The climax of fen succession, which have here resulted in a development of a fen carr, was reached during the pollen subzone AL 3, which correlates with the Gerzensee oscillation. The short cooling of the Gerzensee oscillation is possibly linked to increasing drier conditions causing a further lowering of the water level. A comparable situation is documented in the sedimentary succession of the Brandenburgian Paddenluch, where the climax of fen development is also reported below the LST (pollen subzone AL 3; comp. STRAHL 2005; KosSLer 2010).

The pollen and macro remain data indicate that the vicinity of the Niedersee was mostly covered with a tree population of willows, birch trees and aspen. Based on the 
sporadic findings of Alnus-pollen, the occurrence of alder is assumed. This assumption is supported by contemporaneous pollen and macro remains of Alnus from the Baltic Sea island of Wolin (LATA£ova \& BorówKA 2006), which clearly indicate the presence of Alnus in the southern Baltic region during the Allerød.

Regarding the previous sections from the centre part of the Niedersee taken by Bozhm-Hartmann (1937) and STRAHL \& ANDERS in 1986 (unpublished) compared to the present section of the southern margin, it became obvious that sedimentation of these sections started with a distinct time delay not before the Allerød or potentially during the Older Dryas (see Fig. 2). This led to the conclusion that the area of the Niedersee, which is today the deepest part of the basin, must have previously been filled by a dead ice block. The ongoing deep dead ice melting, which was particularly caused by the climatic amelioration of the Allerød Interstadial (STRAHL 2005), has subsequently led to a significant extension of the Niedersee basin during this time interval.

\subsubsection{Section interval 1.23-1.70 m: Younger Dryas}

The section interval starts with brownish calcareous organic silts (1.23-1.24 m), which are followed by dark brownishgrey, more or less carbonate-free organic silts $(1.24-1.52 \mathrm{~m})$. The uppermost part of the section interval $(1.6-1.7 \mathrm{~m})$ is characterized by yellowish-brown calcareous organic mud, which is very rich in molluscs. A specific feature within the sedimentary record is that the sediments between 1.45$1.46 \mathrm{~m}$ can be traced back to solifluction processes, which is indicated by a differing pollen record characterized by increasing values of pre-Quaternary sporomorphs and reworked pollen of Pinus (Fig. 3).

This section interval represents the 7th pollen zone, which is attributed to the Younger Dryas (= YD in Fig. 3), i.e., the last climatic deterioration of the Weichselian Late Glacial. The pollen zone reveals increasing values of $\mathrm{fu}$ niperus, grasses (Poaceae) and heliophilic herbaceous taxa (e.g. Artemisia, Empetrum, Chenopodiaceae). In contrast to the birches, a considerable decrease in Pinus can be observed. Especially at the end of Younger Dryas, a remarkable expansion of heather (Ericaceae p.p.) and of the thermophilic Filipendula is documented trough the pollen record as well. Within the riparian and aquatic flora, the buttercup (Ranunculus acer-type) and the water buttercup (R. trichophyllus-type; pollen types sensu ANDERSEN 1961) show an expansion, whereas only isolated records of Selaginella and Botrychium spores are documented. Compared to the Allerød Interstadial, a distinct decline in Equisetum is generally proven, but an ultimate increase, similarly to the Ericaceae and to Myriophyllum spicatum, can be observed at the end of the Younger Dryas. Instead, the spread of ferns documents the replacement of the horsetails; but a more specific classification of these ferns is not possible due to the not preserved diagnostic perispore of the monolete spores. The proof of further water plant pollen (pondweeds, hornworts) is infrequent and particularly concentrated at the beginning and at the end of the pollen zone. Towards the top an increase in algae, in remains of planarians and in resting eggs of rotifer (Filinia hofmanni-type) is proven, which provides evidence for an advancing climatic amelioration at the end of the Younger Dryas.

Terrestrial plant macro remains from the samples M12 (1.23-1.35 m), M13 (1.35-1.45), M14 (1.46-1.52 m), M15 $(1.52-1.56 \mathrm{~m})$ and M16 (1.56-1.70 m) are mostly composed of bud scales of willow. Compared to the Allerød Interstadial, a distinct decrease in aspen is shown due to the rare macro fossil record, but few remains of aspen (bud scales) indicate that it could seemingly resist the climatic deterioration of Younger Dryas in this region. But it cannot be excluded with certainty that these few remains of aspen are reworked. Evidence for an opening of vegetation and of climatic cooling is given by a few records of dwarf birch (Betula nana, M15). Several seeds of sedges (Carex rostrata, Carex spp.) and few proofs of rush (funcus) document the riparian vegetation. The frequent occurrences of nutlets from the water buttercup (Ranunculus sect. Batrachium spp.) indicate that aquatic vegetation was firstly dominated by these plants. Ranunculus trichophyllus var. eradicatus (= $R$. confervoides) or Ranunculus trichophyllus s.str. come into consideration as producers of the seeds, but only based on the highly variable nutlets identification on species level is certainly not possible. At first, stoneworts are only proven by single records of gyrogonites/oospores (samples M12, M13), but in the course of the Younger Dryas an increase in abundances and diversity (Chara spp., Nitella opaca) is evident (M14, M15). At the top of section interval (sample M16) a distinct shift from a Batrachium-lake to a Charalake is observable, which is documented by the numerous gyrogonites/oospores of the Charales.

The sediments of samples M12, M13, and M14 are more or less free of calcareous materials and have therefore provided only very few remains of the calcareous fauna. Nevertheless, the presence of ostracods (most probably C. candida, Potamocypris, C. ovum) is proven by its remains of organic skins as well as internal moulds from which the calcareous shell has been leached away. Changes are visible from $1.52 \mathrm{~m}$ upward (sample M15) due to the record of several calcareous shells of ostracods (C. candida, Limnocythere inopinata, C. ovum, Pseudocandona compressa-group) from the sediments, but greater abundances of calcareous shells and increasing diversities are only documented from the top of the section interval (sample M16). With H. reptans, Cyclocypris serena, Potamocypris villosa, Cypridopsis vidua and Fabaeformiscandona protzi (Tab. 1, Fig. 5) five further ostracod species occur. The increase in abundance and diversity of the ostracods correlates to the change of the lake conditions indicated by the stoneworts.

The mollusc fauna shows a similar pattern as the ostracods. The lowermost samples M12, M13, and M14 have only provided a few shell fragments, which, apart from three exceptions (Gyraulus (A.) crista, M12; Radix, Valvata, M14), are not determinable. Again changes are documented through the fossil content of sample M15, which bear a greater quantity of gastropod and bivalve shells. But the highest abundances and diversity within the mollusc fauna are repeatedly documented in sample M16 from the top of the section interval. The gastropods show more an increase in abundance than in diversity. Whereas sample M15 has provided five species of gastropods (Radix balthica, Lymnaea stagnalis, Myxas glutinosa, Valvata aff. alp- 
estris, Valvata cristata), sample M16 has bore six species. Myxas glutinosa and Valvata cristata could not be detected in sample M16, however, three other species are proven (Gyraulus (A.) crista, Gyraulus laevis, Hippeutis complanatus). The frequent occurrence of Valvata aff. alpestris is remarkable, which, compared with other Weichselian sites, appeared relatively late in the Niedersee. The taxonomic status of Valvata aff. alpestris is debatable. Such a morphotype is common in Late Glacial/Early Holocene sediments from Central and Northern Europe (KRIENKE et al. 2006; KOSSLER 2010), but in previous articles these gastropods are still listed as $V$. piscinalis or as subspecies of piscinalis (e.g. Jaeckel 1956; Mania 1967; ØKLAND 1990; Turner et al. 1998). Based on its shell morphology they resemble V. alpestris (comp. GLÖER 2002; GLÖER \& ZETTLER 2005), which required clear and oligotrophic lakes as habitat. But it cannot be excluded that the shells from the Weichselian/Early Holocene sites belong to a new independent species of Valvata. In contrast to the gastropods, the bivalves show a distinct increase in abundances and diversity as well. Whereas sample M15 have offered only three species of pea mussels (P. subtruncatum, P. nitidum, Sphaerium corneum), sample M16 has provided eight species. Beside the three species listed before, P. milium, P. casertanum, P. obtusale f. lapponicum, P. hibernicum and P. pulchellum also appeared.

Whereas the calcareous remains are at first extremely underrepresented, the presence of other fossil objects like organic-walled remains and bone fragments give evidence of further organism groups within the Niedersee. For the first time, the presence of the freshwater bryozoan Cristatella mucedo is proven by its resting eggs (floatoblasts). These resting eggs are relatively frequent in the lowermost samples M12, M13, M14, but they show a distinct decline in sample M15 and are not proven in sample M16. Even though $C$. mucedo is quite indifferent in respect to trophic conditions and tolerates a wide range in $\mathrm{pH}$, it prefers generally slightly acidic conditions, but it disappears in

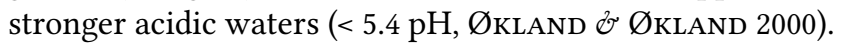
Related to the poor record of calcareous shells in samples M12, M13, M14, the record of C. mucedo additionally indicates that the water of the newly established lake was first low in $\mathrm{pH}(<6.5)$ and therefore unfavourable for calcareous organism groups.

In contrast to the older lake sediments, the samples of this section interval have provided several head capsules of chironomids (Tab. 2). Only the calcareous mud of the uppermost sample M16 has provided only a few head capsules. Most probably the decline in the fossil record of the chironomids can be traced back to taphonomic processes, which could also explain the lacking evidence of this organism group in the older lake sediments of the Niedersee. Here, the records of chironomids are first dominated by head capsules of the Corynocera ambigua-type (see Tab. 2). Subordinately proven are head capsules of the Microtendipes pedellus-, the Chironomus anthracinus-, the Dicrotendipes notatus-, the Sergentina coracina-, the Tanytarsus lugens-, the Cladotanytarsus mancus-, the Psectrocladius sordidellus-, the Propsilocerus aquatilis-type, etc. (see Tab. 2). But within the uppermost sample M16, head capsules of the Corynocera ambigua-type are lacking.

Gemmules of the freshwater sponge Ephydatia fluviatilis are found in sample M15 for the first time and show a distinct increase in abundance in sample M16. According to ØKLAND \& ØKLAND (1996), Ephydatia fluviatilis is a rather hard water habitats preferring freshwater sponge. Moreover, the sediments of this section interval have yielded

\begin{tabular}{|c|c|c|c|c|c|c|c|c|}
\hline & $\begin{array}{l}\text { Chironomids from the } \\
\text { Niedersee section }\end{array}$ & $\begin{array}{l}0 \\
\text { II } \\
\stackrel{2}{\Sigma} \\
\text { ₹ } \\
\Sigma\end{array}$ & $\begin{array}{l}0 \\
\text { II } \\
\text { II } \\
\text { m } \\
\Sigma\end{array}$ & $\begin{array}{l}0 \\
\text { II } \\
\text { II } \\
\Sigma \\
\Sigma\end{array}$ & $\begin{array}{l}0 \\
\text { II } \\
\text { II } \\
\text { ñ } \\
\Sigma\end{array}$ & $\begin{array}{l}0 \\
\stackrel{0}{1} \\
\text { II } \\
0 \\
\underline{\Sigma} \\
\Sigma\end{array}$ & $\begin{array}{l}\frac{m}{\alpha} \\
\text { II } \\
\\
\Sigma \\
\Sigma\end{array}$ & $\begin{array}{l}0 \\
\underline{a} \\
\text { II } \\
\infty \\
\tilde{\sigma} \\
\Sigma\end{array}$ \\
\hline \multirow{6}{*}{ 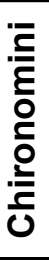 } & Chironomus anthracinus-type & 8 & 1 & 4 & 10 & 2 & & \\
\hline & Dicrotendipes notatus-type & & 1 & & 4 & & & \\
\hline & Microtendipes pedellus-type & 6 & 2 & 7 & 3 & 4 & & 2 \\
\hline & Polypedilum nubeculosum-type & & & & & & & \\
\hline & Cryptochironomus sp. & & & & 1 & 2 & & \\
\hline & Sergentia coracina-type & & & 2 & & & & \\
\hline \multirow{6}{*}{ 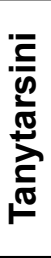 } & Cladotanytarsus mancus-type & & & & & & & \\
\hline & Corynocera ambigua-type & 26 & 47 & 34 & 27 & & & 3 \\
\hline & Paratanytarsus austriacus-type & 6 & & & & & & \\
\hline & Tanytarsus pallidicornis-type & 1 & & & & & & \\
\hline & Tanytarsus lugens-type & 4 & 2 & & & & & \\
\hline & Tanytarsus spp. & 2 & 1 & 1 & & & & \\
\hline \multirow{6}{*}{ 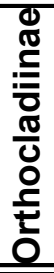 } & Orthocladiinae indet. & 8 & 2 & & 1 & & & \\
\hline & Hydrobaenus conformis-type & 1 & 1 & & & & & \\
\hline & Propsilocerus lacustris-type & 4 & 3 & 3 & 2 & & & \\
\hline & Metriocnemus terrester-type & 1 & & & & & & \\
\hline & Psectrocladius spp. & & $?$ & 1 & & & & \\
\hline & Psectrocladius sordidellus-type & & & & & 1 & & \\
\hline * & Procladius & & 1 & 2 & 1 & 1 & & \\
\hline
\end{tabular}

Tab. 2: Numbers of head capsules of chironomid taxa within the samples M12-M16 (Younger Dryas) and M18 (Preboreal) of the Niedersee. Samples are correlated with their stratigraphic classification. *Head capsules of the Tanypodinae.

Tab. 2: Anzahl von Kopfkapseln der Chironomiden aus Sedimenten der füngeren Dryas (Proben M12-M16) und des Präboreals (Probe M18). *Kopfkapseln der Tanypodinae. 
evidence for the water fleas by their resting eggs (Daphnia pulex-group, Semicephalus sp.), for the water mites (Hydrozetes cf. lacustris), and for fish, which are continuously documented during the Younger Dryas. Evidence for the presence of spike and stickleback is given in sample M16 by their characteristic bone remains.

The data indicate that the continuing rise of the water level, which is still documented at the end of the Allerød Interstadial, led to a re-establishment of a small lake within the Niedersee depression at the beginning of the Younger Dryas. This is shown by a distinct change from fen deposits to lacustrine sediments. The occurrence of the ostracod Fabaeformiscandona protzi, which is a cold stenothermal winter form preferring permanent small water bodies and lakes (KLIE 1938; MEISCH 2000), gives evidence for a balanced water level. The pollen record from the Niedersee, which is comparable with other Younger Dryas sites in Northern Germany, also gives evidence for more humid conditions. The drowning of several depressions with the onset of the Younger Dryas is a well-known phenomenon, not only from Northern Germany (STRAHL 2005; KosSLER 2010), but also from other sites in Europe (e. g. LATA£owA \& Borówka 2006; Bos, Bohncke, \& Janssen 2006). This supra-regional signal in the sedimentary record gives evidence that the lake development is not only influenced by local processes of the deep melting of dead ice, but rather related to a colder and more humid climate. This is in accordance with the results of LATA£OWA \& BoRówKA (2006), whose data from the Baltic Sea island of Wolin indicate at first a more humid climate and then drier conditions for the Younger Dryas, which are subsequently linked to an increase in aeolian processes (comp. also KAISER 2004). In this context, solifluction processes like the one proven here, and wind-born sediments of the Younger Dryas are also known from the Baltic Sea island of Wolin (LATAŁowA \& BorówKa 2006) and the Rugian sites Herthamoor and Hölle (Strahl 1999; Strahl \& Keding 1996). The sedimentary and biogenic record of the Younger Dryas succession of the Paddenluch (Brandenburg) reveals such division in two parts as well (KossLer 2010), indicating at first cooler and more humid conditions and later a change to increasing warmer and slightly drier terms. With the record of the Niedersee a further site reflects a corresponding climatic development during this time interval. But in contrast to the Rugian site Hölle (Fig. 1; Strahl \& Keding 1996), whose sedimentary record ceased with deposits of solifluction processes, the depression of the Niedersee was sufficiently filled with water allowing for continual limnic sedimentation.

Furthermore, even though the climatic cooling of the Younger Dryas is more pronounced here in the pollen record than in the sites located further south (STRAHL 2005), the climatic deterioration is particularly related to the winter temperatures and to the length of the winter season. In this context, the decrease in Pinus, which is here considerably more obvious as in Brandenburg (STRAHL 2005), is possibly related to its frost-sensitive seedlings (LATAŁOWA, ToBolski \& NALEPKA 2004). The remains of biota clearly indicate that temperatures during the growing season were sufficiently warm enough for intermediate and even thermophilic taxa. According to ØKLAND \& ØKLAND (2000), the freshwater bryozoan C. mucedo frequently occures at water temperatures between $11-20{ }^{\circ} \mathrm{C}$ and has its optimum at temperatures between $16-20{ }^{\circ} \mathrm{C}$. This suggests that summer temperatures of the Younger Dryas reached at least $>11{ }^{\circ} \mathrm{C}$ in this region. According to VorRen et al. (2009), the occurrence of $C$. mucedo indicates summer temperatures suitable for the birch forest (mean July temperature $>12^{\circ} \mathrm{C}$ ). The occurrence of chironomid head capsules of the Corynocera ambigua-type is generally regarded as an indicator of arctic and subarctic conditions (e.g. PINDER \& REISs 1983; Mosch \& SCHARF 2002). But BRODERSEN \& LiNDEgAARD (1999) have shown that Corynocera ambigua can tolerate a wide range of ecological conditions and is also proven from warm-tempered lakes $\left(\sim 20^{\circ} \mathrm{C}\right)$. PORINCHU $\&$ CWYNAR (2000) stated that this species is rather linked to lakes of the boreal forest zone and has therefore its main distribution south of the northern tree limit. Certainly indications for cooler temperatures are given through few records of the cold-stenothermic species Tanytarsus lugens (M12, M13, M14) and Sergentina coracina (M14), which are able to colonize shallow lakes under colder climatic conditions, but these species occur here in an extremely subordinated way. Nevertheless, Sergentia coracina does not only occur in very cold conditions, ANTONSSON et al. (2006) quoted an optimum mean July temperature of $13{ }^{\circ} \mathrm{C}$ for this taxon. The record of taxa preferring intermediate temperatures like the Microtendipes pedellus-type (11-17 ${ }^{\circ} \mathrm{C}$, Brooks, Langdon \& Heiri 2007) and the Propsilocerus aquatilis-type as well as the occurrence of more thermophilic species like the Cladotanytarsus mancus-type and Dicrotendipes notatus-type give evidence that the summer temperatures were not too low during the Younger Dryas. Therefore, as already suggested through the freshwater bryozoan $C$. mucedo, the chironomid assemblages indicate a mean July temperature of at least $>11{ }^{\circ} \mathrm{C}$ based on the occurrence of warmer conditions preferring chironomids (e.g. Microtendipes pedellus), but most probably it is assumed that temperatures were generally higher. This correlates to the studies of ISARIN (1997), ISARIN, RENSSEN \& VANDENBerghe (1998) and IsARIN \& BoHncke (1999), which have demonstrated that the Younger Dryas cooling has strongly affected the winter temperatures, but not with the same magnitude as the summer temperatures. According to ISARIN, RENSSEN \& VANDENBERGHE (1998), minimum mean July temperature for the coldest part of the Younger Dryas was not colder than $11{ }^{\circ} \mathrm{C}$. The increase of temperatures towards the top of the section interval (latest Younger Dryas) is also reflected by the chironomids, which are now dominated by intermediate and thermophilic species (Microtendipes pedellus, Chironomus anthracinus, Psectrocladius sordidellus). This correlates well with the expansion of the thermophilic Filipendula and of heather at the end of the Younger Dryas, which is also known from other sites in Mecklenburg-Pomerania (KRIENKE et al. 2006) and Brandenburg (РорРSснӧтZ \& STRAHL 2004), and which obviously predicts the future climatic amelioration of the Holocene. A further evidence of increasing temperatures and changes in $\mathrm{pH}$ towards the top of the section interval is given by the record of gemmules of the rather hard water preferring freshwater sponge Ephydatia fluviatilis. According to ØKLAND \& ØKLAND (1996), this sponge 
generally shows greater abundances under warmer conditions. In this context, the nearly complete lack of calcareous remains in the lowermost samples of this section is not caused by extremely low temperatures; instead, it can be traced back to unfavourable living conditions for the calcareous organisms and to a poor preservation potential of calcareous materials due to rather acidic $\mathrm{pH}$-values. Nevertheless, the presence of $C$. mucedo indicates that $\mathrm{pH}$ was not $<5.4$ (ØKLAND \& ØKLAND 2000).

\subsubsection{Holocene}

\subsubsection{Section interval 1.7-1.95 m: Preboreal}

The sedimentary succession of this section interval shows a tripartite division. The lowest part $(1.7-1.8 \mathrm{~m})$ is characterized by yellowish-white lake marls, which are extremely rich in molluscs. Between 1.8-1.9 m, the sediments are composed of light brownish calcareous organic silts. Then, the top (1.9$1.95 \mathrm{~m}$ ) consists of brownish calcareous organic silts.

Based on the pollen analyses this part of the Niedersee section is attributed to the 8th pollen zone, which corresponds to the early Holocene (Preboreal, = PB in Fig. 3). Within the pollen record, the distinct climatic amelioration of the Holocene is at first shown by a peak in funiperus, and then subsequently in birch trees reflecting once again the expansion of these arboreal taxa (Fig. 3). Although the values of Pinus are increasing steadily, they show no final dominance over the birches. Pollen of Salix spp. and Populus are continuously documented, but the record of these taxa like those of funiperus generally shows a declining trend during the Preboreal. With the exception of the thermophilic Filipendula, whose pollen values reveal a distinct expansion at the onset of the Holocene, herbaceous taxa are generally declining. Among other pollen of heather (Ericaceae p.p., Calluna), umbelliferous plants, Galium, composite plants, Rosaceae, Thalictrum, Rumex, Caryophyllaceae, and Artemisia occur more or less permanently. Noticeable is the distinct peak of the Poaceae in the medium range of the section interval, which correlates with a decline in birches. The local vegetation, which was previously dominated by the Cyperaceae and Equisetum, is at first displaced by Typha latifolia and by marsh fern (Thelypteris palustris), at which the latter appears with a slight delay in time. In contrast to the Younger Dryas, a decline in remains of green algae, rotifers, planarians, water fleas and chironomids, which are also documented within the pollen samples, is observable.

With the exception of some badly preserved oospores of Chara, the yellowish-white lake marls (sample M17, 1.7-1.8 m) shows a lack in plant macro remains, which is maybe related to taphonomic processes. The spreading birch as a response to the early Holocene warming is therefore at first documented by macro remains in the samples M18 (1.82-1.9 m) and M19 (1.9-1.95 m). Even though the fossil record is not rich in specimens, the expansion and the presence of birch trees (e.g. Betula pubescens) are documented through some findings of nutlets and cat skins. Evidence for the renewed spread of aspen is given toward the top of this section interval (sample M19) due to the record of several bud scales. The wetland flora is mainly documented by seeds of Carex spp. and the stinging nettle (Urtica dioica). Noteworthy is the appearance of poppy ( $\mathrm{Pa}-$ paver, M19), which is here proven for the first time. The climatic amelioration of the Early Holocene is also reflected by the aquatic flora with the occurrence of the thermophilic soft hornwort (Ceratophyllum submersum), which prefers meso- to eutrophic conditions (CASPER \& KRAUSCH 1981). The subordinated presence of the common Mare's tail (Hippuris vulgaris) is documented through one seed in sample M18. Beyond the transition Younger Dryas/Holocene the stoneworts are still some of the dominant elements of the aquatic vegetation, but abundances are firstly low within the lake marls (sample M17). A distinct increase of the stoneworts is documented in sample M18, but then they decline distinctly towards the top of the section.

The ostracod fauna resembles that of the late Younger Dryas (sample M16, Tab. 1, Fig. 5), but abundances are distinctly higher. Especially the lake marls (sample M17) are extremely rich in ostracods. Within the ostracod record, Cypria ophthalmica and the thermophilic Notodromas monacha appear for the first time, but these species are subordinately proven. The most frequent taxa are still Candona candida, Limnocythere inopinata, Herpetocypris reptans and Fabaeformiscandona protzi (Tab. 1, Fig. 5), Cyclocypris laevis and Cypridopsis vidua occur as well. Abundances and diversity of ostracods decline toward the top of this section interval, and the permanent water bodies preferring Fabaeformiscandona protzi are no longer proven in the upper part of the section interval (sample M19).

Regarding the diversity of the mollusc fauna, no distinct change is observable with the onset of the Holocene, but abundances are remarkably higher. The gastropod fauna is mainly composed by Valvata aff. alpestris, Radix balthica, Lymnaea stagnalis, Gyraulus laevis, Gyraulus crista, Hippeutis complanatus and Valvata cristata, for the first time appear Acroloxus lacustris, Bathyomphalus contortus, and Anisus vortex. The bivalve fauna consist of Sphaerium corneum, Pisidium milium, $P$. nitidum, $P$. subtruncatum, $P$. casertanum, and $P$. hibernicum. The mollusc fauna show the highest diversity in sample M17 and M18; a distinct decline in diversity, especially within the bivalve fauna, is documented towards the top of the section interval (Tab. 1).

Few head capsules of chironomids are proven within sample M18 (Tab. 2), only three of the Corynoceras ambigua-type and two of the Microdentipes pedellus-type give evidence of this organism group.

Fish remains, mainly stickleback, are documented in all samples of this section interval. The record of one fish scale gives evidence of Perca fluviatilis (sample M18).

Changes in vegetation caused by the climatic amelioration of the Holocene are clearly documented within the pollen record and are comparable to the contemporaneous pollen record of the Rugian Herthamoor (STRAHL 1999; ENDTMANN 2002); it shows a similar pattern as the one already shown with the onset of the climatic warming of the Allerød Interstadial. The warming is also reflected by the aquatic flora. The appearance of the thermophilic (Ceratophyllum submersum) indicates markedly increased mean July temperature. According to BEHRE, HöLzER \& LEMDAHL (2005) and KüHL et al. (2002), the optimum mean July temperature is $>19^{\circ} \mathrm{C}$ for this species. A further evidence of re- 
markably warmer conditions is given by the occurrence of Notodromas monacha. According to VieHberg (2006), this taxon has its optimum water temperature at $21.7{ }^{\circ} \mathrm{C}$ with regard to maturity and reproduction. The warmer and more humid climatic conditions of the early Holocene (RENSSEN \& ISARIN 2001) generally led to an improvement of living conditions and to an increase in lake productivity, which is well-documented by a distinct increase of abundances and diversity of aquatic biota. But from $1.8 \mathrm{~m}$ onward a change in sedimentation is visible, which reflects changes in the water balance. The change in sedimentation correlates with the distinct peak of the Poaceae and the monolete fern spores, with a small peak of Typha latifolia and with a decline of the birch population (Fig. 3). It is most like that the signal in the pollen record is a local phenomenon, because mainly the birch is affected. But if the lowering of water level is related to climatic changes, it could be related to the Rammelbeek oscillation sensu BоHNCKE \& HoEK (2007). In contrast to van der HAMMEN \& WiJMSTRA (1971), these authors interpret the approximately 300 years lasting Rammelbeek oscillation more as a palaeohydrological event, which is caused by a drier climate, rather then a cooling phase. Nevertheless, only with the data of the section from the southern margin of the Niedersee depression, the Rammelbeek oscillation cannot be proven with certainty, because the sedimentary succession reveals a hiatus. When the pollen record is compared with those of the adjacent Credner See (LANGE, Jeschke \& KNAPP 1986), it becomes evident that the Preboreal is preserved incompletely. The lacking evidence of Corylus, which shows an early appearance within the pollen record of the Credner See, supports the assumption that the accumulation of Preboreal sediments ceased before this arboreal floral element immigrates into the habitat. Due to its position, the section of the southern margin was more affected by a low water level than the centre of the Niedersee. The data indicate that the edges of the Niedersee felt dry during the Preboreal and during the following Boreal, which led consequently to a hiatus within the sedimentary succession. In contrast, the centre of the Niedersee is characterized by a remarkably thicker succession of Preboreal and, furthermore, even Boreal sediments (Fig. 2, comp. BoEHM-Hartmann 1937), but as explained in chapter 2, these sediments are no longer accessible for further studies. Nevertheless, the fen peat layers as documented by BoEHm-Hartmann (1937) and ANDERs \& STRAHL (unpubl.) reveal that the centre of the Niedersee was also influenced by fluctuating water levels (Fig. 2). This development in sedimentation correlates to other contemporaneous sites of shallow water bodies in northern Germany (e.g. KAISER 2004; STRAHL 2005), whose sedimentary records were also interrupted by hiatuses. These can be traced back to a distinct lowering of water levels, which was caused by warmer and drier climatic conditions during the late Preboreal and Boreal (comp. LANG 1994; KAISER 2004).

\subsubsection{Section interval $1.95 \mathrm{~m}-2.09 \mathrm{~m}$ : Atlantic and onwards}

The lower part $(1.95-1.99 \mathrm{~m})$ of the uppermost section interval is characterized by blackish fen peat. Between 1.99-2.04 m, intercalations of the blackish fen peat with yellowish-white, calcareous organic silty mud are observable. From $2.04 \mathrm{~m}$ onward, the sedimentation continues with this yellowish-white, calcareous organic silty mud, whose accumulation ultimately ceased at $2.09 \mathrm{~m}$.

The pollen spectra of these sediments allow for establishing the 9th pollen zone, which is attributed to the Atlantic (= $\mathrm{AA} / \mathrm{JA}$ in Fig. 2, 3) or to even younger sediments. The pollen record revealed now several proofs of thermophilic arboreal taxa like Quercus, Ulmus, Corylus, Alnus, Carpinus, lime tree (Tilia) and fir (Abies). But in contrast to Betula and Pinus, these taxa obviously did not play an important role within the forest vegetation; the subordinated values are not illustrated in Fig. 3. Pollen of Filipendula, umbelliferous plants, composite plants and Rosaceae reflect the non arboreal vegetation. Noteworthy is the appearance of ribwort (Plantago lanceolata), whose occurrence is often related to an anthropogenic influence, but further proofs of anthropogenic activities like pollen of cereals could not be detected.

The blackish fen peat (sample M20, 1.95-1.99 m) has provided several bud scales of aspen, and a few bud scales of willow. This indicates that in the surroundings of the Niedersee these arboreal taxa still played an important role in the forest vegetation. The riparian flora is documented through few remains of sedges and several seeds of marsh trefoil (Menyanthes trifoliata). Only few proofs of the aquatic flora are subordinately documented through a few gyrogonites/oospores of the Charales and one seed of Hippuris vulgaris. With the onset of the yellowish-white, calcareous organic silty mud (sample M21, 2.0-2.09 m), a distinct change within the plant record is documented. From this point on, no evidence of arboreal taxa is proven in the sediments. Menyanthes trifoliata is also no longer represented in the plant record and replaced by Urtica dioica and the lamb's-quarter (Chenopodium album). According to DüLl \& KutZELNIGg (2005), the latter taxon is regarded as hemerophilous species, which prefers areas developed by man. Few records of the stoneworts give at least evidence for temporary water bodies.

In contrast to the older record of the Niedersee, distinct changes are observable within the fauna. Whereas only a few calcareous remains of terrestrial gastropods and ostracods (C. candida, Pseudocandona sp.) are preserved in sample M20, sample M21 has revealed an excellent record of calcareous organism.

The ostracod fauna is now characterized by Eucypris pigra, Cryptocandona vavrai, Pseudocandona sucki and the subordinately occurring $C$. candida; it shows a totally different composition compared to previous assemblages (Tab. 1, Fig. 5).

Likewise, the mollusc fauna of this time interval is obviously distinct from the previous ones (Tab. 1). The sample M21 provided a rich mollusc fauna with a high diversity, but the majority of taxa belonged to terrestrial gastropods; a detailed description of these terrestrial gastropods will be given by MENZEL-HARLOFF \& STRAHL (in prep.). Limnic gastropod assemblages are now characterized by Aplexa hypnorum, Galba truncatula, Segmentina nitida, Anisus leucostoma, and Valvata cristata. Only two pea mussels, P. casertanum and P. obtusale, are proven.

The data indicate that after the hiatus a gradually increasing ground water level led again to a soaking of the 
habitat. Due to the higher water level, accumulations of fen peat start again, which pass then into the calcareous organic silty mud (meadow chalk). The pollen data suggest that these sediments are distinctly younger than Preboreal and Boreal and belong most probably to the Atlantic or even younger time periods (? Subboreal). This applies to the sediments of the section of the northern margin of Niedersee as well (Fig. 2), which have revealed comparable pollen spectra and mollusc assemblages. However, the rather poor preservation of the sporomorphs in this time interval does not allow for a more precise dating.

The fossil record of biota clearly indicates fen habitats. The here proven Menyanthes trifoliata is a typical plant of wet and moderate nutrient-rich fens or transitional mire habitats, which are characterized by carbonate-free and moderate acidic conditions (CASPAR \& KRAUSCH 1981). The poor record of aquatic biota indicates the presence of shallow, most likely temporary water bodies. From $1.99 \mathrm{~m}$ upward, distinct changes with regard to sediment composition, biota and $\mathrm{pH}$ are visible, which suggest that the habitat at least changed into an open alkaline fen. This correlates well with the documented lack of arboreal taxa in sample M21. The frequent records of terrestrial gastropods, of which several belong to hygrophilous species (e.g. Succineidae indet., Carychium minimum, Vertigo antivertigo etc.) are also typical for such habitats (KERNEY, CAMERON \& JungBluth 1983; ZetTler et al. 2006; pers. comm. MenZeLHARLOFF). No evidence of a larger and permanent water body can be detected, but the occurrence of shallow temporary water bodies is reflected by the aquatic fauna. According to KLIE (1938) and Meisch (2000), the ostracods Pseudocandona sucki, Eucypris pigra, and Cryptocandona vavrai prefer small temporary pools. This also applies to the limnic gastropod assemblages consisting of Aplexa hypnorum, Galba truncatula, Segmentina nitida, Valvata cristata, and Anisus leucostoma, which are characteristic of such habitats (GLÖER 2002). The also proven pea mussels $P$. casertanum and $P$. obtusale are not uncommon in such unstable aquatic habitats, especially $P$. obtusale is typical in temporary water bodies (ZETTLER et al. 2006; KosSLER 2010).

The natural succession of the Niedersee ceased with these fen deposits; this can be traced back to a lowering of the ground water level, which is most likely linked to drier climatic conditions. Since that time, no further fen development took place within the Niedersee depression. Finally, the sedimentary succession of the Niedersee was buried by younger colluvial deposits.

\subsection{Stratigraphic position of the Niedersee record and its importance in comparison to other Late Glacial sites in northeast Germany}

According to Krienke (1996, 2003) the formation of the dead ice kettles of Jasmund can be traced back to the Pomeranian ( 17,600 cal. years BP, comp. LiTT et al. 2007) and Mecklenburg phases ( 17,000 to 15,000 cal. years BP, comp. LITT et al. 2007) of the late Weichselian Pleniglacial. On this account, sedimentation within the Niedersee depression took place no sooner than after this time.

When the sections presented here are compared with the documented sections of previous studies
(Boehm-Hartmann 1937; Anders \& Strahl, unpubl.), it becomes evident that the various sections of the Niedersee differ significantly in thickness and stratigraphic range. Whereas the centre of the depression is characterized by a maximum thickness of lake sediments, the section of the southern margin reveals less thick, but in return the oldest deposits (Fig. 2). Here, based on the analysed pollen record and AMS ${ }^{14} \mathrm{C}$-dating an age reaching back into the Weichselian Pleniglacial is proven, whereas the oldest lake sediments from the centre are only of Allerød (section of 1986) or of probably Older Dryas age (Fig. 2, see discussion in chapter 3.1.1.6). Moreover, only a Holocene (Atlantic) age is proven for the lake sediments of the northern margin (Fig. 2). The different stratigraphic ranges of the sections clearly indicate that the dead ice of the Niedersee kettle hole was influenced by an early pre-Allerød melting, but the meltdown of dead ice took place in a non-uniform manner. This led to a gradual deepening, opening and a partly time-lagged refilling within the depression. Nevertheless, due to its exceptional sedimentary record reaching back into the Weichselian Pleniglacial, the Niedersee occupies a special place in relation to Late Glacial archives, because several other contemporaneous depressions in Northern Germany were completely sealed with dead ice until the Allerød (comp. STRAHL 2005).

Thus, with the Niedersee a further out crop can be added to the survey of pre-Allerød archives of MecklenburgWest Pomerania, which were listed previously by KRIENKE ¿ Strahl (1999), Strahl (2005) and Krienke et al. (2006). So far, only few pre-Allerød archives like Rappin, Rugard, Gingster Moor and especially Gingster Haide (comp. LANGE, JeschKe, KNAPP 1986) are known from Rügen. Two other new records of the mainland of Mecklenburg-West Pomerania (Müritz: JANKE in LAMPE et al. 2006; Frauentogsee nearby Penzlin: STRAHL 2008) can be added to the list as well. Like the sequences of Tessin (KRIENKE \& STRAHL 1999), Gingster Haide (LANGe, JeschKe, KnApP 1986) and Grimmen (KRIENKE et al. 2006), the Niedersee shows a higher stratigraphical resolution compared to the remaining records.

\section{Conclusions}

In summary, the obtained data indicate that the sedimentary record of the Niedersee can mainly be traced back to shallow lake environments, which were repeatedly affected by fluctuating water levels causing the development of fens. The pollen record and pollen-based vegetation and climate reconstructions as well as the AMS ${ }^{14} \mathrm{C}$-dating suggest that accumulation of sediments began directly after the retreat of the Weichselian ice sheet. The presented data reveal that the aquatic organisms indicate the first response to the climatic amelioration at the beginning of the Weichselian Late Glacial and that the pollen record shows a slight delay in time in reacting to the warming. Changes in sedimentation and assemblages of biota were not only affected by the changes in temperatures, but also through changes in water balance, trophic level and in $\mathrm{pH}$. The combined results of the different proxies demonstrate that the Niedersee system responded well to changing climatic conditions; this allows for a clear definition of the onset and termination 
of the interstadials/stadials of the Weichselian Late Glacial and the onset of the Holocene. The record of the Niedersee turned out to be an excellent archive for reconstructing changes in the lake and catchment environments driven by the combination of global, regional and local processes.

\section{Acknowledgements}

We would like to acknowledge financial support of the "Gemeinsamen ständigen Forschungskommission des Akademischen Senats und des Präsidiums der FU Berlin" for the AMS ${ }^{14} \mathrm{C}$-datings. Our sincere gratitude is further extended to H. Menzel-Harloff for support during working in the field and discussion, to Maike Glos for laboratory assistance, to Dr. A. Czekay and Dr. U. Schudack for correcting the English, to Dr. P. Tarasov for helpful discussion and to R. Staff for calibrating ${ }^{14} \mathrm{C}$-dates to IntCal09. We would also like to thank Dr. W. Hoek, Dr. Th. Huebener, and further anonymous reviewers for their comprehensive and very helpful review of the manuscript.

\section{References}

AlM, G. (1916): Monographie der schwedischen Süsswasser-Ostracoden nebst systematischen Besprechungen der Tribus Podocopa. - Zoologiska Bidrag från Uppsala, 4: 1-248.

Andersen, S. T. (1961): Vegetation and its Environment in Denmark in the Early Weichselian Glacial (Last Glacial). - Danmarks Geologiske Undersøgelse, II. R., 75: 1-175.

Andresen, C.S., Björck, S., Bennike, O., Heinemeier, J. \& Kromer, B. (2000): What do $\triangle 14 \mathrm{C}$ changes across the gerzensee oscillation/GI-1b event imply for deglacial oscillations? - Journal of Quaternary Science, 15 (3): 203-214.

Antonsson, K., Brooks, S.J., Seppä, H., Telford, R.J. \& Birks, H.J.B (2006): Quantitative palaeotemperature records inferred from fossil pollen and chironomid assemblages from Lake Gilltjärnen, northern central Sweden. - Journal of Quaternary Science, 21 (8): 831-841.

Behre, K.-E., Hölzer, A. \& LEMDAHL, G. (2005): Botanical macro-remains and insects from the Eemian and Weichselian site of Oerel (northwest Germany) and their evidence fort he history of climate. - Vegetation History and Archaeobotany, 14: 31-53.

BENZIE, J.A.H. (1989): The distribution and habitat preference of ostracods (Crustacea: Ostracoda) in a coastal sand-dune lake, Loch of Strathbeg, north-east Scotland. - Freshwater Biology, 22: 309-321.

BIRKs, H.H. (1993): The importance of plant macrofossils in late-glacial climatic reconstructions: an example from western Norway. - Quaternary Science Reviews, 12: 719-726.

Björck, S., Walker, M.J.C., Cwynar, L.C., Johnsen, S., Knudsen, K.-L., Lowe, J.J., Wohlfarth, B. \& INTIMATE Members (1998): An event stratigraphy for the Last Termination in the North Atlantic region based on the Greenland ice-core record: a proposal by the INTIMATE group. - Journal of Quaternary Science, 13: 283-292.

Boehm-Hartmann, H. (1937): Spät- und postglaziale Süßwasserablagerungen auf Rügen. I. Pollenanalytische und paläontologische Untersuchungen. - Archiv für Hydrobiologie, 31: 1-37.

Boнncke, S.J.P. \& HoEk, W.Z. (2007): Multiple oscillations during the Preboreal as recorded in a calcareous gyttja, Kingbeekdal, The Netherlands. - Quarternary Science Reviews, 26: 1965-1974.

Bos, J.A.A., BoHncke, S.J.P. \& JANSSEN (2006): Lake-level fluctuations and small-scale patterns during the late glacial in The Netherlands. - Journal of Paleolimnology, 35: 211-238.

Brodersen, K.P. $\circlearrowleft$ LindegAARD, C. (1999): Mass occurrence and sporadic distribution of Corynocera ambigua Zetterstedt (Diptera, Chironomidae) in Danish lakes. Neo- and palaeolimnological records. - Journal of Paleolimnology, 22: 41-52.

Brooks, S.J. \& Birks, H.J.B. (2000a): Chironomid-inferred Late-glacial air temperatures at Whitrig Bog, southeast Scotland. - Journal of Quaternary Science, 15(8): 759-764.

Brooks, S.J. \& BIRKs, H.J.B. (2000b): Chironomid-inferred late-glacial and early-Holocene mean July air temperatures for Kråkenes Lake, western Norway. - Journal of Paleolimnology, 23: 77-89.
Brooks, S.J., LANGdon, P.G. \& HeIRI, O. (2007): The Identification and Use of Palaearctic Chironomidae Larvae in Palaeoecology. - Quarternary Research Association, Technical Guide no. 10: 276 pp.; London (MWL, Pontypool).

Casper, S.J. \& Krausch, H.-D. (1981): Pteridophyta und Anthophyta. 2. Teil: Saururaceae bis Asteraceae. - In: Ettl, H., Gerloff, J. \& Heynig, H. (Eds.): Süßwasserflora von Mitteleuropa, 24: 409-942; Stuttgart (Gustav Fischer Verlag).

De Klerk, P., Janke, W., Kühn, P. \& Theuerkauf, M. (2008): Environmental impact of the Laacher See eruption at a large distance from the volcano: Integrated palaeoecological studies from Vorpommern (NE Germany). - Palaeogeography, Palaeoclimatology, Palaeoecology, 270: 196-214.

Düll, R. \& Kutzelnigg, H. (2005): Taschenlexikon der Pflanzen Deutschlands. Ein botanisch-ökologischer Exkursionsbegleiter zu den wichtigsten Arten. - 6. Auflage: 577 pp.; Wiebelsheim (Quelle \& Meyer).

ENDTMANN, E. (2002): Das „Herthamoor“ - ein palynostratigraphisches Leitprofil für das Holozän der Insel Rügen. - Greifswalder Geographische Arbeiten, 26:143-147.

Firbas, F. (1949): Spät- und nacheiszeitliche Waldgeschichte Mitteleuropas nördlich der Alpen. 1. Band: Allgemeine Waldgeschichte. 480 pp.; Jena (Gustav Fischer Verlag).

Frenzel, P. \& Viehberg, F.A. (2004): Checklist of Recent and Quaternary ostracods (Crustacea) from freshwater, brackish and marine environments in Mecklenburg-Vorpommern, NE Germany. Revista Española de Micropaleontologia, 36: 29-55.

Frenzel, P., Keyser, D. \& Viehberg, F.A. (2010): An illustrated key and (palaeo)ecological primer for Postglacial to Recent Ostracoda (Crustacea) of the Baltic Sea. Boreas, 39: 567-575.

Frömming, E. (1954): Biologie der mitteleuropäischen Landgastropoden. 404 pp.; Berlin (Duncker \& Humblot).

Funrmann, R. (1973): Die spätweichselglaziale und holozäne Molluskenfauna Mittel- und Westsachsens. - Freiberger Forschungshefte, C 278: $1-121$.

Fuhrmann, R., Schirrmeister, L. \& Pietrzeniuk, E. (1997): Ostrakoden und Mollusken aus den weichselspätglazialen Sedimenten des Biesenthaler Beckens (N-Brandenburg, Barnim). - Zeitschrift für geologische Wissenschaften, 25(5/6): 489-511.

GLÖER, P. (2002): Die Süßwassergastropoden Nord- und Mitteleuropas. Die Tierwelt Deutschlands, 73: 327 pp., Hackenheim (ConchBooks).

GlöER, P. \& MEIER-Brook, C. (2003): Süßwassermollusken - Ein Bestimmungsschlüssel für die Bundesrepublik Deutschland. - Deutscher Jugendbund für Naturbeobachtungen, 13. Auflage: $134 \mathrm{pp}$.

Glöer, P. \& ZetTler, M. L. (2005): Kommentierte Artenliste der Süßwassermollusken Deutschlands. - Malakologische Abhandlungen Museum für Tierkunde Dresden, 23: 3-26.

GöRsDORF, J. \& K. KAISER (2001): Radiokohlenstoffdaten aus dem Spätpleistozän und Frühholozän von Mecklenburg-Vorpommern. - Meyniana, 53: 91-118.

Hoek, W.Z., Bohncke, S.J.P., Ganssen, G.M. ひ Meijer, T. (1999): Lateglacial environmental changes recorded in calcareous gyttja deposits at Gulickshof, southern Netherlands. - Boreas, 28: 416-432.

IsARIN, R.F.B. (1997): Permafrost distribution and temperatures in Europe during the Younger Dryas. - Permafrost and Periglacial Processes, 8: 313-333.

IsARIN, R.F.B. $\mho$ BoHnCKe, J.P. (1999): Mean July temperatures during the Younger Dryas in Northwestern and Central Europe as inferred from climate indicator plant species. - Quaternary Research, 51: 158-173.

IsARIN, R.F.B., RENSSEN, H. \& VANDENBERghe, J. (1998): The impact of the North Atlantic Ocean on the Younger Dryas climate in northwestern and central Europe. - Journal of Quaternary Science, 13(5): 447-453.

Iversen, J. (1954): The late-glacial flora of Denmark and its relation to climate and soil. - Danmarks Geologiske Undersøgelse, II Række, 80: 87-119.

JAECKEL, S.G.A. (1956): Süßwassermollusken aus spät- und postglazialen Ablagerungen in Schleswig-Holstein. - Schriften des Naturwissenschaftlichen Vereins für Schleswig-Holstein, 28(1): 76-89.

JanZ, H. (1994): Zur Bedeutung des Schalenmerkmals „Marginalrippen“ der Gattung Ilyocypris (Ostracoda, Crustacea). - Stuttgarter Beiträge zur Naturkunde, Serie B, 206: 1-19.

Johnsen, S.J., Clausen, H.B., DansgaArd, W., Gundestrup, N.S., Hammer, C.U., Andersen, U., Andersen, K.K., Hvidberg, C.S., DAhl-Jensen, D., Steffensen, J.P., Shoji, H. Sveinbjörnsdóttir, A.E., White, J.W.C., Jouzel, J. \& Fisher, D. (1997): The $\delta^{18} \mathrm{O}$ record along the Greenland Ice Core project deep ice core and the problem of possible Eemian climatic instability. - Journal of Geophysical Research, 102: 26397-26410. 
KAISER, K. (2004): Geomorphic characterization of the Pleistocene - Holocene transition in Northeast Germany. - In: Terberger, Th. ひ ERIKSEN, B.V (Eds.): Hunters in a changing world. - Internationale Archäologie - Arbeitsgemeinschaft, Symposium, Tagung, Kongress, 5: 53-73.

Kerney, M., Cameron, R.A.D. \& Jungbluth, J.H. (1983): Die Landschnecken Nord- und Mitteleuropas: 384 pp.; Hamburg (Paul Parey Verlag).

KienAST, F. (2002): Die Rekonstruktion der spätquartären Vegetationsund Klimageschichte der Laptewsee-Region auf der Basis botanischer Großrestuntersuchungen. - Dissertation Universität Potsdam: 116 pp.

KLIE, W. (1938): Krebstiere oder Crustacea III: Ostracoda, Muschelkrebse. - Die Tierwelt Deutschlands und der angrenzenden Meeresteile, 34: 230 pp., Jena (Gustav Fischer Verlag).

KLIEwE, H. (1996): Vulkanasche aus der Eifel in Nordrügen. - Rugia-Journal, 1996: 52-55.

Kolstrup, E. (1979): Herbs as July temperature indicators for parts of the Pleniglacial and Late-Glacial in The Netherlands. - Geologie en Mijnbouw, 58(3): 377-380.

Kolstrup, E. (1980): Climate and stratigraphy in northwestern Europe between 30.000 B.P. and 13.000 B.P., with special reference to The Netherlands. - Mededelingen Rijks Geologische Dienst, 32-15: 181-253.

Kossler, A. (2010): Faunen und Floren der limnisch-telmatischen Schichtenfolge des Paddenluchs (Brandenburg, Rüdersdorf) vom ausgehenden Weichselhochglazial bis ins Holozän - Aussagen zu Paläomilieu und Klimabedingungen. - Berliner paläobiologische Abhandlungen, 11: $422 \mathrm{pp}$.

KrASSKe, G. (1937): Spät- und postglaziale Süßwasserablagerungen auf Rügen. II. Diatomeen aus den postglazialen Seen auf Rügen. - Archiv für Hydrobiologie, 31: 38-53.

KRIENKE, H.-D. (1996): Geologische Karte von Mecklenburg-Vorpommern Karte der quartären Bildungen - Oberfläche bis fünf Meter Tiefe 1 : 200 000, Blatt Stralsund. - Geologisches Landesamt MecklenburgVorpommern; Schwerin.

KRIENKE, H.-D. (2003): Geologische Karte von Mecklenburg-Vorpommern. Erläuterungen zur Karte der quartären Bildungen - Oberfläche bis fünf Meter Tiefe - 1 : 200 000. - Landesamt für Umwelt, Naturschutz und Umwelt Mecklenburg-Vorpommern; Güstrow.

KrienKe, H.-D. \& STrahl, J. (1999): Weichselzeitliche und holozäne Ablagerungen im Bereich der Deponie Tessin bei Rostock (MecklenburgVorpommern) unter besonderer Berücksichtigung des Prä-AllerödKomplexes. - Meyniana, 51: 125-151.

Krienke, H.-D., Strahl, J., Kossler, A. \& Thieke, H. U. (2006): Stratigraphie und Lagerungsverhältnisse einer quasi vollständigen weichselzeitlichen Schichtenfolge im Bereich des Deponiestandortes Grimmen (Mecklenburg-Vorpommern). - Brandenburgische geowissenschaftliche Beiträge, 13: 133-154.

Kühl, N., Gebhardt, CH., Litt, T. ひ Hense, A. (2002): Probability density functions as botanical-climatological transfer functions for climate reconstructions. - Quaternary Research, 58: 381-392.

Kuiper, J.G.J. (1968): Die spätpleistozänen Pisidien des ehemaligen Ascherslebener Sees. - Archiv für Molluskenkunde, 98(1/2): 23-38.

Lampe, R., Meyer, H., Lorenz, S., Janke, W., Viehberg, F., Küster, M. \& ARNDT, S. (2006): Die Müritz Seebohrungen 2004-2006. Umweltgeschichtlich orientierte Sedimentbohrungen zur Rekonstruktion der nacheiszeitlichen Landschafts- und Gewässerentwicklung im MüritzNationalpark. -Abschlussbericht Institut für Geographie und Geologie Ernst-Moritz-Arndt-Universität Greifswald, 108 pp

LANG, G. (1994): Quartäre Vegetationsgeschichte Europas. Methoden und Ergebnisse. - 462 pp., Jena (Gustav Fischer Verlag).

LANGE, E., Jeschke, L. \& KNAPP, H. D. (1986): Ralswiek und Rügen. Landschaftsentwicklung und Siedlungsgeschichte der Ostseeinsel. Teil 1 Die Landschaftsgeschichte der Insel Rügen seit dem Spätglazial. Text und Beilagen. - Schriften zur Ur- und Frühgeschichte, 38: 175 pp.

LataŁowa, M. \& Borówka, R. K. (2006): The Allerød/Younger Dryas transition in Wolin Island, northwest Poland, as reflected by pollen, macrofossils and chemical content of an organic layer separating two aeolian series. - Vegetation History and Archaeobotany, 15: 321-331.

Latałowa, M., Tobolski, K. \& Nalepka, D. (2004): Pinus L. subgenus Pinus (subgen. Diploxylon (Koehne) Pilger) - Pine. - In: Ralska-Jasiewiczowa, M., Latąowa, M., Wasylikowa, K., Tobolski, K., Madeyska, E., Wright, H.E. \& Turner, $\mathrm{CH}_{\text {. }}$ (Eds.): Late Glacial and Holocene history of vegetation in Poland based on isopollen maps. - W. Szafer Institute of Botany, Polish Academy of Science: 165-169; Kraków.

LitT, T. \& STEBICH, M. (1999): Bio- und chronostratigraphy of the Lateglacial in the Eifel region, Germany. - Quaternary International, 61: 5-16.

Litt, T., Behre, K.-E., Meyer, K.-D., Stephan, H.-J. \& Wansa, S. (2007) Stratigraphische Begriffe für das Quartär des norddeutschen Vereis- ungsgebietes. - Eiszeitalter und Gegenwart, 56 (1-2): 7-65.

Lotter, A. F., Eicher, U., Siegenthaler, U. \& Birks, H. J. B. (1992): Lateglacial climatic oscillations as recorded in Swiss lake sediments. Journal of Quaternary Science, 7: 187-204

LožEK, V. (1990): Mollucs in loess, their palaeoecological significance and role in geochronology - principles and methods. - Quaternary International, 7/8: 71-79.

ManiA, D. (1967): Pleistozäne und holozäne Ostracodenvergesellschaften aus dem ehemaligen Ascherslebener See. - Wissenschaftliche Zeitschrift der Martin-Luther-Universität Halle-Wittenberg,16(4) 501-550.

Matveyeva, N.V. (1994): Floristic classification and ecology of tundra vegetation of the Taymyr Peninsula, northern Siberia. - Journal of Vegetation Science, 5: 813-828.

Meisch, C. (2000): Crustacea: Ostracoda. - Süßwasserfauna von Mitteleuropa, Bd. 8/3: 522 pp.; Heidelberg (Spektrum Akademischer Verlag).

Meisch, C., Fuhrmann, R. \& Wouters, K. (1996): Ilyocypris getica Masi 1906 (Crustacea, Ostracoda): Taxonomy, ecology, life history, distribution, fossil occurrence and first record for Germany. -Travaux scientifiques du Musée national d'histoire naturelle de Luxembourg, 23: $3-28$.

Mosch, E.CH. \& Scharf, B.W. (2002): Die subfossile Chironomidenfauna des Schulzensees (Mecklenburg-Vorpommern). - Greifswalder Geographische Arbeiten, 26: 119-122.

MüLLER, U. (2004): Jung-Pleistozän - Eem-Warmzeit bis Weichsel-Hochglazial. - In: KATZUNG, G. (Ed.): Geologie von Mecklenburg-Vorpom mern: 234-242; Stuttgart (E. Schweizerbart'sche Verlagsbuchhandlung).

NüChterlein, H. (1969): Süßwasserostracoden aus Franken. Ein Beitrag zur Systematik und Ökologie der Ostracoden. - Internationale Revue der gesamten Hydrobiologie, 54 (1): 223-287.

ODLAND, A. (1996): Differences in the vertical distribution pattern of Betula pubescens in Norway and its ecological significance. - In: FrenzeL B. (Eds.): Holocene treeline oscillations, dendrochronology and palaeoclimate. - Palaeoclimate Research, 20: 43-59.

ØKLAND, J. (1990): Lakes and snails. Environment and gastropoda in 1.500 Norwegian lakes, ponds and rivers. - 516 pp.; (Dr. W. Backhuys/Oegstgeest).

ØKLAND, K.A. \& ØKLAND, J. (1996): Freshwater sponges (Porifera Spongillidae) of Norway: distribution and ecology. - Hydrobiologia, 330: $1-30$

ØKLAND, K.A. \& ØKLAND, J. (2000): Freshwater bryozoans (Bryozoa) of Norway: distribution and ecology of Cristatella mucedo and Paludicella articulata. - Hydrobiologia, 421: 1-24.

Piechocki, A. (1989): The Sphaeriidae of Poland (Bivalvia, Eulamellibranchia). - Annales Zoologici, 42(12): 249-318.

Pinder, L.C.V. \& ReIss, F. (1983): The larvae of Chironominae (Diptera: Chironomidae) of the Holarctic region - Keys and diagnoses. - In Wiederholm, T. (Ed.): Chironomidae of the holarctic region. Keys and diagnoses. Part 1. Larvae. - Entomologica Scandinavica, Suppl 19: 293-435.

Poppschötz, R. \& Strahl, J. (2004): Fazies- und Pollenanalyse an einem weichselspätglazialen Flusslauf im „Oberen Spreeschwemmfächer“ bei Cottbus. - Berliner Geographische Arbeiten, 96: 69-88

Porinchu, D. F. \& Cwynar, L.C. (2000): The distribution of freshwater Chironomidae (Insecta: Diptera) across treeline near the lower Lena River, Northeast Siberia, Russia. - Arctic, Antarctic, and Alpine Research, 32 (4): 429-437.

Ralska-Jasiewiczowa, M., Wacnik, A., Mamakowa, K. \& Nalepka, D. (2004): Betula L. - Birch. - In: Ralska-Jasiewiczowa, M., LataŁowa, M., Wasylikowa, K., Tobolski, K., Madeyska, E., Wright, H.E. \& Turner, $\mathrm{CH}$. (Eds.): Late Glacial and Holocene history of vegetation in Poland based on isopollen maps. - W. Szafer Institute of Botany, Polish Academy of Science: 57-68 (Kraków).

Reimer, P.J., Baillie, M.G.L., Bard, E., Bayliss, A., Beck, J.W., Blackwell, P.G., Bronk Ramsey, C., Buck, C.E., Burr, G.S., Edwards, R.L., Friedrich, M., Grootes, P.M., Gullderson, T.P., Hajdas, I., HeAton, T.J., Hogg, A.G., Hughen, K.A., Kaiser, K.F., Kromer, B., McCormac, F.G., Manning, S.W., Reimer, R.W., Richards, D.A., Southon, J.R., Talamo, S., Turney, C.S.M., van Der Plicht, J. \& WeyhenMEYER, C.E. (2009): INTCAL09 and MARINE09 radiocarbon age calibration curves, 0-50,000 years cal BP. Radiocarbon, 51(4): 1111-1150.

RENSSEN, H. \& ISARIN, R.F.B. (2001): The two major warming phases of the last deglaciation at $~ 14.7$ and $\sim 11.5 \mathrm{ka}$ cal BP in Europe: climate reconstructions and AGCM experiments. - Global and Planetary Change, 30: 117-153. 
Steusloff, U. (1937): Spät- und postglaziale Süßwasser-Ablagerungen auf Rügen. III. Bemerkungen zu den Mollusken aus den Ablagerungen des Niedersees. - Archiv für Hydrobiologie, 31: 54-57.

Strahl, J. (1999): Die Vegetationsgeschichte des Herthamoores in der Stubnitz (Halbinsel Jasmund, Insel Rügen). - Greifswalder Geowissenschaftliche Beiträge, 6: 437-477.

Strahl, J. (2005): Zur Pollenstratigraphie des Weichselspätglazials von Berlin-Brandenburg. - Brandenburgische geowissenschaftliche Beiträge, 12: 87-112.

Strahl, J. (2008): Pollenanalytische Untersuchung der Bohrung „Am Frauentogsee“, Grapenwerder Bruch bei Penzlin. - Neubrandenburger Geologische Beiträge, 8: 30-41.

Strahl, J. \& Keding, E. (1996): Pollenanalytische und karpologische Untersuchung des Aufschlusses „Hölle“ unterhalb Park Dwasieden (Halbinsel Jasmund, Insel Rügen), Mecklenburg-Vorpommern. - Meyniana, 48: 165-184.

Terberger, T., De Klerk, P., Helbig, H., Kaiser, K. \& Kühn, P. (2004): Late Weichselian landscape development and human settlement in Mecklenburg-Vorpommern (NE Germany). - Eiszeitalter und Gegenwart, 54: 138-175.
Turner, H., Kuiper, J.G.J., Thew, N., Bernasconi, R. Rüetschi, J., WüthRICH, M. \& Gosteli, M. (1998): Atlas der Mollusken der Schweiz und Liechtensteins. - Fauna Helvetica, 2: 527 pp.

VAN Der Hammen, T. \& Wijmstra, T. A. (1971): The Upper Quaternary of the Dinkel valley. - Mededelingen Rijks Geologische Dienst, Nieuwe Serie, 22: 55-214.

vaN GeEL, B. (2001): Non-pollen palynomorps. - In: SMOL, J.P., Birks, H.J.B., LAst, W. (Eds.): Tracking Environmental Change Using Lake Sediments, vol. 3: 99-119; Dordrecht (Kluwer Academic Publishers).

Viehberg, F. (2006): Freshwater ostracod assemblages and their relationship to environmental variables in waters from northeast Germany. - Hydrobiologia, 571: 213-224.

Vorren, K.-D., Elverland, K., BlaAuw, M., Ravna, E. K. \& Jensen, C. A. H. (2009): Vegetation and climate c. 12 300-9000 cal. Yr. BP at Andøya, NW Norway. - Boreas, 38: 401-420.

Zettler, M., Jueg, U., Menzel-Harloff, H., Göllnitz, U., Petrick, S. Weber, E. \& SEemann, R. (2006): Die Land- und Süßwassermollusken Mecklenburg-Vorpommerns. - Beiträge zur floristischen und faunistischen Erforschung des Landes Mecklenburg-Vorpommerns: 318 pp.; Schwerin (Obotritendruck). 